\title{
Akademisyenlerin Yabancı Dil Bilgisi Seviye Tespit Sınavı'nın (YDS) Geçerliğiyle İlgili Tutumlarının Belirlenmesi
}

\author{
Discovering the Attitudes of Academicians Towards the Validity of Foreign \\ Language Proficiency Exam (FLPE)
}

\author{
Okt. Murat Polat
}

Başvuru Tarihi: 05.11.2017

Kabul Tarihi: 29.09 .2018

\section{Öz}

Türkiye'de 2013 yıl itibariyle yabancı dil seviyesi ölçme ve değerlendirmesinde kullanilan Yabancı Dilbilgisi Seviye Tespit Sinavı (YDS) içeriğiyle ilgili akademisyenlerin tutumlarınin belirlenmesi, sinava dair fikirlerinin alınması ve sinavin güçlü ve zayıf yönlerinin ortaya konulması yabancı dil eğitimiyle ilgilenen tüm paydaşlar için yararlı olacaktır. 2015-2016 yilları arasında yapılan bu çalışmada akademisyenlerin YDS konusundaki tutumların belirlemede kullanılmak üzere YDS'nin geçerliğiyle ilgili 12 maddeden oluşan bir ölçek geliştirilmiş, sonrasında yapılan pilot uygulamada ölçeğin açıklayıcı ve doğrulayıcı faktör analizi yapılmış ve ölçeğin güvenilirlik ve geçerlik gibi psikometrik özellikleri incelenmiştir. 3 alt boyutu bulunan ve güvenilir bir veri toplama aracı olduğu kanitlanan bu ölçekle 84 devlet üniversitesinde çalışan 2687 akademisyenden sinavin geçerliğiyle ilgili görüşleri alınmıştır. Araştırmada YDS’nin geçerliği ilgili akademisyenlerin olumlu görüşlere sahip olmadıkları, YDS'nin yabancı dil ölçmede yazma, dinleme ve konuşma soruları içermediğinden bir dil sınavı olarak gerçek anlamda yeterli görülmediği belirlenmiştir. Ayrıca katılımcı akademisyenlerin görüşlerinin cinsiyet ve medeni durum gibi bağımsız değişkenler dikkate alındığında anlaml farklıliklar göstermezken, katılımcıların sınavdan aldıkları puanlar, sinava giriş amaçları ve taşıdıkları akademik unvanlar dikkate alındiğında anlaml farklilıklar gösterdiği tespit edilmiştir $(p<.05)$.

Anahtar Kelimeler: YDS, Geçerlik, Yabancı Dil Yeterlilik, Ölçek Geliştirme, Açıklayııı Faktör Analizi, Doğrulayıcı Faktör Analizi

\begin{abstract}
Discovering the attitudes of academicians towards the Foreign Language Proficiency Exam (FLPE), gathering their ideas on the validity of it and summarizing the strengths and weaknesses of FLPE which has been administered in Turkey as of 2013 to measure and evaluate foreign language competency level would be of great use for all the parties who are directly or indirectly involved in foreign language assessment. In the study, which was carried out between 2015-2016; first, a 12-item-scale to collect data from academicians on validity of FLPE was designed, then it was piloted to do exploratory and confirmatory factor analyses and finally psychometric qualities like validity and reliability of the scale were identified. The data of this study were obtained from 84 state universities with the contribution of 2687 academicians with this new scale, which had 3 factors and identified as a valid and reliable tool after the analyses. The findings revealed the following conclusions: academicians do not have positive opinions about the validity of FLPE; this exam does not include questions to test writing, listening and speaking skills; therefore, the participants do not consider its validity adequate to be a good proficiency test. Moreover, the analyses indicated that gender and marital status of the participants did not create significant differences whereas FLPE results, academic title and the reason why they take this exam created a considerable difference on academicians' attitudes towards the validity of FLPE $(p<.05)$.
\end{abstract}

Keywords: FLPE, Validity, Foreign Language Proficiency, Scale Development Exploratory Factor Analysis, Confirmatory Factor Analysis

Okt. Murat Polat, Anadolu Üniversitesi Yabancı Diller Yüksekokulu, mpolat@anadolu.edu.tr 


\section{Giriş}

Ölçme değerlendirmeyle ilgilenen hemen herkese sorulmuş oldukça yaygın bir soru vardır; ölçmede kullanılan bir testin geçerliği mi güvenilirliği mi daha önemlidir? Yanıt elbette ki her ikisi de olacaktır zira testlerin geçerliği ile ilgili araştırmalar geçerlik ile birlikte güvenilirlik kavramının testlerin uygulanması ve sonuçlarının değerlendirilmesi sürecinde olmazsa olmaz özellikler olduklarını ve herhangi bir testin uygulanmadan önce mutlaka geçerliği ve güvenilirliği ile ilgili çalışmalar yapılması ve ancak tatmin edici sonuçlar alınması halinde söz konusu testin uygulanabileceğini göstermiştir (Çelik, 2000; Ercan ve Kan, 2004; Gür, 2012; Şencan, 2005, Yıldırım, 1983; Yllmaz, 1996). Ancak Brown (1998) testlerin güvenilirliklerin çok önemli olduklarını belirtirken geçerliklerinin ölçme ve değerlendirme uzmanlarını daha önce ilgilendirmesi gerektiğini belirtmiştir. Söz gelimi geçerliği ve güvenilirliği dünyaca bilinen bir testin örneğin TOEFL IBT testinin adayların geometri becerilerini test etmede kullanıldığını düşünelim. $\mathrm{Bu}$ denemeden elde edilecek sonuçlar oldukça güvenilir çıkacaktır çünkü ölçme aracı güvenilirdir ancak elde ettiğimiz skorlar ölçmeyi amaçladığımız geometri becerisi konusunda fikir verebilir mi? Tabi burada asıl mesele ne TOEFL testinin kullanım amacı ne de geometri ölçümünde kullanabileceğimiz yordamlayıc1lığıdır, burada önemli olan bir testin geçerli olmadan da güvenilir sonuçlar verebileceği gerçeğidir. ÖSYM, YDS’nin güvenilirliği ve geçerliği ile ilgili sayısal verileri paylaşmamaktadır ve bu durumda yapılabilecek tek varsayım bu tür hesaplamaların kurum tarafından yapıldığı ve istenilen düzeylerde sonuçlar alındığıdır ki YDS içeriği ve amacıyla ilgili herhangi bir değişiklik yapılmadan uzunca bir süredir uygulanmaktadır.

Türkiye'de yapılan yabancı dil sınavlarının geçerlikleri ile ilgili birtakım çalışmalar yapılmış ve hemen hepsinde bu sınavlara gerek içerik gerekse amaçları ele alınarak yoğun eleştiriler getirilmiştir (Aşkaroğlu, 2014; Gür, 2012; Yavuzer ve Göver, 2012). Tekin (1977) geçerliği herhangi bir ölçeğin ya da testin ölçmeyi amaçladığı özelliği, başka herhangi bir başka özellik karıştırmadan, doğru ölçebilme özelliği olarak tanımlar. Diğer yandan Messick (1996) testin geçerliğinin belirlenen hedefe ulaşma miktarı olduğundan testlerden elde edilecek sonuçların hangi amaçla kullanılacaksa ölçmedeki geçerliğin de o amaca paralel olarak değişeceğini söylemiştir. Bu bulgular aynı za- manda geçerlikle ilgili farklı özelliklerin konuşulması gerekliliğini ve yapılacak tartışmanın bunlar üzerinden maddeler hâlinde yapılmasının daha yerinde olacağını ortaya koyar. Nitekim Henning (1992) geçerliğin çok boyutlu bir olgu olduğunu ve testlerin geçerliği tartışıldığında her bir boyutun ele alınması gerektiğini belirtmiştir. Ercan ve Kan (2004) test geçerliği ile ilgili sınıflamayı aşağıdaki listede vermişlerdir.

- Kapsam geçerliği: Test iddia ettiği kapsamı ölçüyor mu?

- Kriter geçerliği: Testten elde edilen puanlarla önceden belirlenen kriterler arasındaki ilişki güçlü mü?

- Uyum geçerliği: Eş zamanlı olarak, geliştirilen ölçekten elde edilen puanlarla, belirlenen kriter arasındaki korelasyon yüksek mi?

- Yordama geçerliği: Test sonuçları ölçtüğünü iddia ettiği becerilerle ilgili geleceğe dönük veri sağliyor mu?

- Yapı geçerliği: Testte yer alan her madde, testin bütünü ile ilişkili mi?

• Görünüş geçerliği: Test ölçmek istediği şeyi ölçüyor mu?

- Sonuç geçerliği: Test sonucunda ortaya çıkan sonuçlar öğrenci üzerinde olumlu etki yaratıyor mu?

YDS’nin kapsam geçerliği açısından araştırmacılar tarafından sıklıkla eleştirilen içeriğinin gerek Avrupa Konseyi’nin gerekse Millî Eğitim Bakanlığı’nın amaçladığı yabancı dil eğitimi kazanımlarını ölçmeye yönelik olmadığını (Altmışdört, 2010; Gür, 2012; Yavuzer ve Göver, 2012), ağırlıkla içerdiği kelime ve dil bilgisi soruları nedeniyle adayların iletişimsel dil becerilerini ölçebilecek konuşma, dinleme ve yazma gibi becerilerin ölçümünden uzak olduğu ve son olarak içerdiği çeviri soruları nedeniyle uluslararası geçerlikten uzak, sadece Türkçe konuşanların ya da Türkçe bilenlerin yapabileceği bir test olduğu söylenebilir. Bugün bütün dünyada dil becerilerinin geliştirilmesi ve sınanması için hiç olmadığ 1 kadar teknik imkân ve yazılım olmasına rağmen YDS'de hâlâ çoktan seçmeli kelime ve dil bilgisi soruları, üretime değil anlamaya dayalı sorular kullanılması, sınavın günümüzde geçerliğini ve diğer sınavlarla denkliğinin sorgulanmasina neden olabilir. 
YDS’nin üzerinde konuşulması gereken bir diğer yanı ise sınav hakkında kriter geçerliğini sağlama anlaminda akademisyenlerin dile getirdiği düşüncelerdir. YDS sınavından yüksek notlar aldığı hâlde İngilizce konuşmakta zorlanan, söylenenleri anlayamayan veya bir başvuru formunu doldurmakta yardıma ihtiyaç duyan akademisyenlerin olduğu ya da tam aksine adı geçen sınavdan düşük notlar almasına rağmen hedef dilde gayet iyi konuşan, yazan ve dinleme ile ilgili hiçbir sorun yaşamayan adayların çokça görüldüğü farklı çalışmalarda dile getirilmiştir (Aşkaroğlu, 2014; Özmen, 2011). Bu karşıtlıklar sınavın aslında neyi ölçmeyi amaçladığı ve/fakat neyi ölçtüğü konusunda araştırma gerekliliği ortaya çıkarmaktadır.

Uyum geçerliği konusunda en önemli başvuru kaynağ 1 Avrupa Ortak Dil Kriterleri'dir. ÖSYM gerekli eş değerlilik skalalarını vermiştir ancak bunlar ne ölçüde gerçekçidir? ÖSYM'nin belirttiği bu eş değerlilik bilgileri ve bunların nasıl bulunduklarıyla ilgili akademik bir çalışma hâlâ yayınlanmamıştır, sonuçlar tamamen ilgili eș değerlik çalışma grubunun kararları ve çalışmasıdır (ÖSYM, 2015). Acaba YDS'den 8090 aralığında puan alan adaylar TOEFL IBT veya PTE sınavlarına girdiklerinde başarıları ne seviyede olacaktır? Bu konuda da yayınlanmış yeterli eş değerlik çalışması yoktur, yalnızca Bayraktaroğlu’nun (2010, s. 3) çalışmasında konuyla ilgili bir tespit vardır:

"Ülkemizdeki sınavlardan 60 ile 90 arası puanı alarak lisans programına başlayan 50 öğrencinin IELTS s1navına girdikleri zaman, yabancı dille eğitim görebilmeleri için gerekli olan 6.0 düzeyinin çok altında 2.5 - 4.5 arası gibi düşük bir puan aldıkları görülmüştür. Bu uygulamanın, gerçek dışı öğrenim-öğretim amaç ve hedefleriyle, verimsiz, başarısız sonuçlar doğurduğu ve yapılan her türlü maddi yatırıma rağmen ümit edilen beklentileri karşılayamadığı malumdur."

Sınavların eş değerlilikleri üzerinde dikkatle durulduğunda göze çarpan başka bir hususda esas alınan eş değerlilik puanlarının aslında uygulama anlamında birbiriyle çeliştiği gerçeğidir. Örneğin Türkiye’de dil yeterliliğini belgelemek isteyen bir adaydan söz gelimi 85 puan ve üzerinde bir başarı beklenilsin. Aday eğer YDS'den bu puanı alırsa bir sorun yok, TOEFL IBT sınavından 85 puana eş değer 102 almak durumunda ya da IELTS sinavindan ÖSYM esaslarına göre 6,5 almak zorunda, bu aynı zamanda ÖSYM’nin
TOEFL'dan alınan 102 puanı IELTS'den alınan 6,5 puana denk saydığı anlamına gelir. Ancak ETS (English Testing Service) tarafından verilen denklik rakamlarinda 102 puana denk gelen IELTS skorunun 7,5 olduğu açıklanıyor (ETS, 2015). Yani aynı denklik düzeyi için ÖSYM, IELTS sınavından 6,5 istemişken Birleşik Devletler 'de faaliyet gösteren ETS 7,5 istemiştir ve bütün bu denklem birbirine eş sayılmaktadır. ÖSYM tarafından eş değerlilikleri olduğu varsayılan bu üç s1navın eş değerlilik puanları arasındaki bu fark aslında sınavların denkliği anlamında da ne denli bir çelişki yaşandığını ve bizim bu konuda hata yapıyor olabileceğimiz gerçeğini gözler önüne sermektedir.

Bir diğer önemli nokta YDS’nin yordama geçerliği ile ilgili örneklerdir. Sınavda başarı gösteren adayların gelecekteki yabancı dil başarı performansları da sınava paralel olarak yüksek olmalıdır. Erasmus Programi’yla ilgili Avrupa İstikrar Girişimi'nin (ESI, 2014) “Türk Öğrenciler Tecrit ve Erasmus Sorunsalı” adlı araştırmasında ankete katılan ülkeler arasında "Anadiliniz dışında, hangi dilleri sohbet edebilecek seviyede iyi konuşabiliyorsunuz?” sorusuna verilen cevaplara bakıldığında bilinen yabancı dil sayısı bakımından Türkiye'nin ankette 67 ülke arasında son sırada olduğunu görüyoruz. Aynı raporda Türk öğrencilerin iletişim sorunları ve dil yeterlilik düzeyleri üzerinde de sıkça durulması, aslında bu öğrencilerin Erasmus Hareketliliğine katılmadan önce dil yeterliliklerini ispat ettikleri düşünüldügünde oldukça şaşırtıcıdır. Ayrıca YDS’nin yordama geçerliğini sorgulamamıza neden olan bir diğer gerçekse kamuda çalışan personelin yabancı dil yeterliliğine sahip olduğunu KPDS, ÜDS veya YDS gibi sinavlarla belgelemesine rağmen o dilde gerek sözlü gerekse yazılı olarak kendini yeterince ifade edemediği gerçeğidir (Yavuzer ve Göğer 2012). Türkiye’de yabancı dil seviye tespit sınavından yüksek notlar aldığı hâlde konuşamayan hatırı sayılır miktarda aday vardır ki bunların arasında İngilizce öğretmenlerinin de olduğunu bilmek ve halihazırda Türkiye'de yabancı dil eğitimi veren İngilizce öğretmenlerinin yarısından çoğunun konuşma konusunda kendilerini yeterli hissetmediklerinin bizzat kendileri ve ayrıca Millî Eğitim Bakanı tarafından dile getirilmesi hem düşündürücü hem de oldukça üzücüdür (Vatan Gazetesi, 04.01.2008).

Testin geçerliği ile ilgili bir diğer husus yapı geçerliğidir. YDS’nin içerdiği sorulardan 6 tanesi çeviri soru- 
larıdır, bunlar Türkçeden İngilizceye ve İngilizceden Türkçeye olmak üzere iki bölümde sorulur ve adayların sıklıkla en iyi performans gösterdikleri bölümlerin başında gelir. Ancak bu tip çeviri soruları aynı zamanda şu sorunu da akla getiriyor: sınava giren adayın anadili ya Türkçe değilse? Ayrıca bu sınavın amacı aynı anda her iki dili ölçmek olmadığına göre, örneğin Filistinli bir aday sınava girdiğinde sırf Türkçesi diğer adaylardan daha kötü olduğu için İngilizce notu daha düşük mü olacaktır? Hatırlanacağı üzere yapı geçerliği testin bütününün aynı amaca hizmet etmesidir. Yani YDS sorularının tamamı yabancı dil seviyesini ölçmek üzerine olmalıdır, başka bir dili değil; aksi hâlde sınavın yapı geçerliği kuşku uyandırır (Elatia, 2013; Sun ve Cheng, 2013). Brown (1998) yapısal geçerliği bulmaya çalıştığımız yapı olarak tarif ediyor. Bir başka deyişle eğer amacımız İngilizce bilgisini ölçmekse ve bir aday sırf Türkçesi diğer aday kadar iyi olmadığından YDS'den Türkçesi daha iyi olandan düşük not alıyorsa ölçeğin yapısal geçerliğinin problemli olabileceği düşünülmelidir.

Geçerlik kavramının alt başlıklarından bir diğeri de görünüş geçerliğidir. Görünüş geçerliği deyince testteki soruların aslında ne amaçla hazırlandığ değil neyi ölçüyor göründügüdür. Daha basit örneklerle tanımlamak gerekirse bir yabancı dil testi açılıp bakıldığında içerisinde yabancı dil soruları olmalı, testi alıp bakan, başlı̆̆ını okuyan herkesin de bu konuda net bir fikri olmalı, kafalarda "Bu yabancı dil testi mi?" sorusunu uyandırmamalıdır. Heaton (1988) görünüş geçerliğinin özellikle çok katılımcıya uygulanan testlerde önemli bir olgu olduğunu ve testi alan adayın motivasyonu ve adayın zihnindeki test geçerliği üzerinde ciddi etkilerinin olduğunu belirtmiştir.

Sınavların geçerliğiyle ilgili son olarak üzerinde durulması gereken geçerlik boyutu sonuç geçerliğidir. YDS ortaya koyduğu sonuçlar itibariyle ne kadar geçerlidir ve bu sonuçların paydaşlar üzerindeki etkileri araştırıldığında YDS olumlu etkiler bırakmış mıdır? Özellikle akademisyenlerin yabancı dilden bu denli soğumaları, neredeyse hiç konuşma, yazma ve dinleme becerilerinin üzerinde durmamalarının nedeni birçok araştırmada (Gür, 2012; Karaman, 2015; Kozallık ve Karakaya, 2015) YDS'de sorulan soruların türü ve içeriği olarak belirtilmiştir. Öte yandan birçok akademisyenin yabancı dil çalışmalarını sırf dil bilgisi kurallarını öğrenme, kelime ezberleme ve okuma parçası çözümleme olarak belirlediği ve bu yüzden konuşma, dinleme ve yazma gibi belki de asıl ihtiyaç duyacağı becerileri geri plana attığı bilinen bir gerçektir.

Türkiyede yabancı dil eğitiminde istenilen verimin alınamaması, yabancı dil eğitiminin paydaşların pek çoğunu tatmin etmeyen dilbilgisi kurallarının kullanımı ve okuduğunu anlama gibi becerilerin eğitimi üzerine odaklanması, Avrupa ve diğer dünya ülkelerinin yabancı dil eğitimindeki başarıları ve çeşitliliğgi düşünüldüğünde Türkiye’nin bu alandaki yetersizliği ve Türkiye'de uygulanan yabancı dil sınavlarının sorunun bir parçası olduğu birçok araştırmacı tarafından dile getirilmiştir. British Council tarafından 2015 yılında yayınlanan “Türkiyede Yükseköğretim Kurumlarındaki İngilizce Eğitimi” (British Council Report, 2015) adlı raporda İngilizce yeterliğiyle ilgili problemin altı çizilerek Türkiye’nin 'İngilizce sorununun' lisans ve lisansüstü eğitimin kalitesini olumsuz yönde etkileyen ve akademik kaynaklara erişimi, uluslararası araştırma yayımlarını ve gerek akademik personelin, gerekse yurt dişında okumak isteyen öğrencilerin hareketliliğini kısıtlayan başlıca unsurlardan olduğu belirtilmiştir. Yine

Türkiye Ekonomi Politikaları Araştırma Vakfının (TEPAV) 2011 yılında yayınladığ raporda, Türkiye İngilizce Yeterlilik Endeksinnde 44 ülkenin dâhil edildiği bir araştırmada Suudi Arabistan, Endonezya, Vietnam gibi ülkelerin gerisinde kalarak Kazakistan'ın önünde sondan ikinci olmuş ve bu durumun nedenleri arasında modern dil testlerinde dil becerileri başlığ altında yer alan iletişim becerileri konusunda Türk adayların yeterince donanımlı olmadıkları ifade edilmiştir. Bir başka deyişle Türk öğrencilerin İngilizceyi bilmedikleri değil, yeterince iyi kullanamadıkları söylenebilir. Bu sorunun birçok nedeni olabilir ancak bu çalışmada Türkiyede uygulanan yabancı dil yeterlik sınavlarının ölçme geçerliği ve bu sınavların öğrencilerin dil öğrenme alg1 ve yöntemleri üzerindeki ket vurma etkileri incelenecektir.

Türkiyedeki YDS’nin içeriğiyle ilgili önceki bölümlerde sözü edilen temel bazı sorunlar sadece konuyla ilgilenen araştırmacıların değil, bu sınava giren ya da girmeyi planlayan adayların, eğitimcilerin, akademisyenlerin ve hatta üniversite yönetimlerinin bildiği bir husustur. YDS sınavının Türkiyede sözü geçen bazı 
üniversitelerce kabul görmeyişinin nedenleri de elbette ki bu saydığımız problemler olabilir. YDS’nin gerek ölçtüğü gerek ölçmediği yabancı dil becerilerinin öğrenciler, eğitimciler ve eğitim programları üzerinde oluşturduğu olumsuz etkiler sadece bir geçerlik sorunu değil aynı zamanda Türkiye'deki yabancı dil eğitiminin nasıl olması gerektiğiyle ilgili temel bir konudur.

YDS'nin hedef yabancı dilde konuşma, yazma ve dinleme gibi önemli becerileri ölçmeyişi Türkiye'de yabancı dilde verilen eğitimin içeriğini olumsuz yönde etkilemekle kalmayıp adayların çoktan seçmeli sorularda doğru seçeneği bulmak adına israrla kelime ezberleme, dil bilgisi yapılarına odaklanma, test stratejileri geliştirip verilen seçenekleri eleme gibi aslında yabancı dil eğitiminin hiç de içermediği becerilere kafa yormalarına neden olmaktadır. Ayrıca YDS'nin yabancı dil öğrenimi ve yetkinliğiyle ile ilgili adaylar üzerinde yarattığı etkiler de araştırılması ve üzerinde durulması gereken önemli bulgulardır. Bu nedenle bu araştırma YDS’nin geçerliğiyle ilgili görüşleri derleyip nedeniyle hem sinavla ilgili karar vericilere Türkiye'deki akademisyenlerden ÖSYM'nin yaptığı yabancı dil sınavlarıyla ilgili geri dönüt sağlayıp sınavla ilgili gerekli iyileştirmelerin ne yönde yapılmasıyla ilgili veri sağlayacak hem de alan yazında ihtiyaç duyulan YDS’nin geçerliği ile ilgili veri toplama aracı ve bulgu eksikliğini giderebilecektir.

\section{Araştırma Soruları}

Türkiyedeki devlet üniversitelerinde görev yapan akademisyenlerin YDS'nin geçerliğiyle ilgili tutumlarının araştırılması amaçlanan bu çalışmada veri toplamak amacıyla önce bir ölçek geliştirilmesi hedeflenmiş ve verinin bu ölçek kullanılarak toplanması ve analiz edilmesi amaçlanmıştır. Buradan hareketle belirlenen araştırma soruları aşağıda listelenmiştir:

1. Akademisyenlerin YDS’nin geçerliğiyle ilgili tutumlarının belirleneceği ölçeğin güvenilirlik düzeyi, açıklayıcı ve doğrulayıcı faktör analizi sonuçları nelerdir?

2. Akademisyenlerin YDS’nin geçerliğiyle ilgili tutumları ne yöndedir ve bu tutumlar cinsiyet, medeni durum, sınav puanı, unvan, çalışma alanı ve katılımcıların sınava giriş nedenleri göz önüne alındığında anlamlı farklılıklar göstermiş midir?

\section{Araştırmayla İlgili Varsayımlar}

Bu araştırmada:

1. YDS’nin faktör yapısı ve yüklerinin hesaplandığı, sınavın birbirini tekrar etmeyen faktörler içerdiği,

2. Güvenirlik testlerinin yapıldığ 1 ve sinavın hedeflenen güvenirlik katsayılarının üzerinde olduğu,

3. 2013 y1lından itibaren yapılan her bir YDS'nin bir diğeriyle benzer zorluk seviyesinde olduğu varsayılmaktadır.

\section{Araştırmayla İlgili Sınırlılıklar}

Bu araştırma:

1. Türkiye'deki devlet üniversiteleri,

2. Çalışmaya katılımcı olmayı kabul eden akademisyenlerden toplanan veriyle sinırlidır.

\section{Araştırma Deseni}

2015-2016 yılları arasında Türkiyedeki devlet üniversitelerinde görev alan akademisyenlerin katılımıyla yapılan bu araştırmada genel tarama yöntemi kullanılmıştır.

\section{Araştırmanın Evren ve Örneklemi}

2015-2016 yılları arasında Türkiye'deki devlet üniversitelerinde görev alan akademisyenler bu araştırmanın evrenini oluşturmuş ve araştırmada kullanılan veri bu evren içerisinden kolayda örnekleme yoluyla toplanmıştır. Araştırma için bu örnekleme yöntemi seçilmiştir çünkü olabildiğince fazla akademisyene ulaşmak hedeflenmiştir ve cevaplanması için gönderilen görüş formalarının ne kadarının cevaplanacağı kestirilemediğinden dolayı kolay ulaşılabilinen katılımcılar çalışma için tercih edilmiştir. Araştırma için yaklaşık 20000 olası katılımcıya elden form vererek, posta ile göndererek ve elektronik posta kullanmak suretiyle ulaşılmış ancak toplamda 2697 katılımcidan veri toplanılabilmiştir. Çalışmada olabildiğince fazla devlet üniversitesinden mümkün olan en çok sayıda katılımcıdan veri toplamak hedeflenmiş ancak katılım oranı kestirilemediğinden tabakalı örnekleme yoluna gidilmemiştir. 


\section{Katılımcılar}

Türkiyede yabancı dil yeterliği tespiti için yapılan YDS’nin geçerliğiyle ilgili yapılan bu araştırma için araştırmacı tarafından geliştirilem veri toplama formu kullanılarak yapılan bu çalışmaya 84 devlet üniversitesinden toplam 2697 akademisyen katılmıştır. Elde edilen 2697 katılım formundan 14 adedi aşağ1daki nedenlerden ötürü çalışmaya dâhil edilmemiş ve katılımcı kesin adedi 2683 olarak belirlenmiştir.
Katılım formlarından;

1. 7 tanesinde kişisel bilgiler eksik bırakılmış,

2. 4 tanesinde çalışma için geliştirilen ölçeklerin bir kısmına veya tamamına cevap verilmemiş,

3. 3 tanesinde ise Likert ölçeklerdeki maddelerin tamamı işaretlenmiştir.

Tablo 1. Katılımcı Dağııımı - Cinsiyet

\begin{tabular}{llll}
\hline Cinsiyet & Frekans & $\%$ & Toplam \% \\
\hline Kadın & 1388 & 51.7 & 51.7 \\
Erkek & 1295 & 48.3 & 100.0 \\
Toplam & 2683 & 100.0 & \\
\hline
\end{tabular}

Tablo 1'de görüldüğü üzere çalışmaya katılan kat1lımcıların \%51.7 ‘si kadın, geri kalan \%48.3’lük kısmı erkektir. Cinsiyet değişkeni ele alındığında çalışmaya katılan akademisyenler arasında dengeli bir dağılım görülmüştür. Katılımcıların medeni durumları Tablo 2'de verilmiştir.

Tablo 2. Katııımcı Dağııımı - Medeni Durumu

\begin{tabular}{lccr}
\hline Medeni Durum & Frekans & $\%$ & Toplam \% \\
\hline Bekâr & 1399 & 52.1 & 52.1 \\
Evli & 1284 & 47.9 & 100.0 \\
Toplam & 2683 & 100.0 & \\
\hline
\end{tabular}

Katılımcıların medeni durumlarına bakıldığında cinsiyette olduğu gibi yine dengeli bir dağılım görülmüss, katılımcıların \%52.1'inin bekâr, \%47.9'unun evli olduğu çıkmıştır. Problem durumunun araştırılması esnasında madde havuzu için veri toplanırken kat1lımcılardan YDS ile ilgili katılımcı fikirlerinin nelere göre değișebileceği sorulmuş ve özellikle kadın ka- tılımcılar evli olup olmamanın önemli bir bağımsız değişken olabileceğinin altını çizmişler ve evli kadın katılımcıların sınava hazırlanmakta daha zorlanacağını ve bu durumun göz önünde bulundurulması gerektiğini belirtmişlerdir. Katılımcılarla ilgili bir diğer değişken olan katılımcıları yaşı Tablo 3’te verilmiştir.

Tablo 3. Katılımcı Dağılımı - Yaş

\begin{tabular}{lccc}
\hline Yaş & Frekans & $\%$ & Toplam \% \\
\hline $22-27$ & 429 & 16.0 & 16.0 \\
$28-33$ & 868 & 32.4 & 48.3 \\
$34-39$ & 676 & 25.2 & 73.5 \\
$40+$ & 710 & 26.5 & 100.0 \\
Toplam & 2683 & 100.0 & \\
\hline
\end{tabular}


Yaşları ele alındığında katılımcılar arasında yine dengeli bir dağılım görülmüş, en yüksek oran olan \%32,4'lük dilim 28-33 yaş arası katılımcıları gösterirken 22-27 yaş arası k atılımcıların oranı \%16'yla en düşük dilimdir ki bu oran katılımcıların tamamının akademisyen olduğu düşünüldüğünde doğal sayılabilir.

Tablo 4. Katılımcı Dağılımı - Unvan

\begin{tabular}{lccc}
\hline Akademik Unvan & Frekans & $\%$ & Toplam \% \\
\hline Uzman & 75 & 2.8 & 2.8 \\
Okutman & 463 & 17.1 & 19.9 \\
Öğr. Gör. & 326 & 12.3 & 32.2 \\
Arş. Gör. & 848 & 31.6 & 63.8 \\
Yrd. Doç. Dr. & 561 & 20.9 & 84.7 \\
Doç. Dr. & 230 & 8.6 & 93.3 \\
Prof. Dr. & 180 & 6.7 & 100.0 \\
Toplam & 2683 & 100.0 &
\end{tabular}

Katılımcıların akademik unvanlarına göz atıldığında, çalışmaya 848 kişiyle \%31,6 oranla en çok araştırma görevlilerinin katıldığını, en az katılımın ise $\% 2,8$ oranla uzman kadrosundan geldiğini görüyoruz. Türkiye'deki devlet üniversitelerinde 2015 yilı itibariyle çalışan toplam 127.908 akademik kadronun \%30,8'lik kısmını 41734 kadroyla araştırma görevlile- ri, \%6,83'lük bölümünü 18.706 adet profesör kadrosu, \%3,3'lik kısmın 3.607 kadroyla uzman kadrosundaki akademisyenler oluşturur ki çalışmaya katılan akademisyenlerin (\%31,6 araştırma görevlileri, \%2,8 uzmanlar ve $\% 6,7$ profesörler) oranları da bu oranlara oldukça yakın çıkmış ve elde edilen verinin temsilciliğini desteklemiştir.

Tablo 5. Katılımcı Dağıımı - Alan

\begin{tabular}{llll}
\hline Alan & Frekans & $\%$ & Toplam \% \\
\hline Sosyal Bil. & 681 & 25.4 & 25.4 \\
Fen Bil. & 733 & 27.3 & 52.7 \\
Sağlık. Bil. & 165 & 6.1 & 58.9 \\
Eğitim Bil. & 881 & 32.8 & 91.7 \\
Diğer & 223 & 8.3 & 100.0 \\
Toplam & 2683 & 100.0 & \\
\hline
\end{tabular}

Tablo 5’te katılımcı akademisyenlerin çalışma alanları genel başlıklar altında verilmiştir. Çalışmaya en çok sırasıyla eğitim, fen ve sosyal bilimlerden akademisyenler katılırken en az sağlık bilimlerinden katılım sağlamıştır. Diğer bilimler başlı̆̆ı altında ise havacılık iletişim bilimleri, gibi alan başlıkları yer almıştır. Tablo 6'da çalışmaya katılan akademisyenlerin sınava giriş nedenleri ana başlıklar hâlinde verilmiştir. 
Tablo 6. Katılımcılar - YDS'ye Giriş Nedeni

\begin{tabular}{lllc}
\hline YDS'ye Giriș Nedeni & Frekans & $\%$ & Toplam \% \\
\hline Tazminat Alma & 478 & 17.8 & 17.8 \\
Lisansüstü Eğt. Alma & 872 & 32.5 & 50.3 \\
Kadro alma & 1010 & 37.6 & 88.0 \\
Yab. Dil. Sev. Öğr. & 182 & 6.8 & 94.7 \\
Diğer & 141 & 5.3 & 100.0 \\
Toplam & 2683 & 100.0 & \\
\hline
\end{tabular}

Akademisyenlerin \%37,6'sının YDS'ye giriş nedeni "akademik kadro alma" olarak belirlenmiş, bir diğer yüksek oran olan \%32,5'lik kısım ise sınava "lisansüstü eğitim alma” amacıyla girdiğini belirtmiştir. "Diğer" başlı̆̆ 1 altında ise üniversitelerde tamamı İngilizce olarak verilen derslere girebilme yetkinliği alma, değişim programlarına katılma gibi nedenler görülmüştür.

\section{YDS Geçerlik Tutum Ölçeğinin Geliştirilmesi}

Araştırmada YDS’nin geçerliğiyle ilgili akademisyen görüşlerinin toplanması amaçlanmaktadır ancak alanyazında bu sınav için geliştirilmiş, geçerliği ve güvenirliği sınanmış ve uzmanlarca onaylanmış araçlar olmadığı için YDS’nin geçerliğiyle ilgili bir tutum ölçeği geliştirilmiştir. Ölçek geliştirme süreciyle ilgili birçok araştırmacı (Cohen ve Sverdlik, 2013; Crocker ve Algina, 1986; DeVellis, 2014; Şeker ve Gençdoğan, 2014) farklı aşamalardan bahsetmişlerdir dolayısıyla bu araştırmacıların birçoğunun ortak olarak öngördüğü aşamalar belirlenmiş ve ölçek geliştirme sürecinde aşağıdaki aşamalar takip edilmiştir:

1. Araştırmanın amacı akademisyenlerin YDS’nin geçerliğiyle ilgili görüşlerini incelemektir. Bu doğrultuda öncelikle farklı alanlardan ve farklı akademik unvanlara sahip 12 gönüllü akademisyenin katıldığı bir toplantıda katılımcılara YDS'nin geçerliği ile ilgili görüşleri sorulmuş ve toplantı süresince katılımcıların sınavın geçerliğiyle ilgili söyledikleri önemli hususlar not edilmiş ve elde edilen bu veri madde hazırlamada ve olası gruplamaların belirlenmesinde kullanılmıștır.

2. Sonraki aşamada ilk safhada katılımcılardan elde edilen veri incelenerek sınavin geçerliğiyle ilgili önemle üzerinde durulan bir gurup önemli sorgu belirlenmiş ve bu sorgulanan hususların sınavın özellikle kapsam, kriter ve yordama geçerliğiyle ilgili olduğu belirlenmiştir.

3. YDS'nin kapsam, kriter, ve yordama geçerliğiyle ilgili direkt olmayan ancak sinavin bu geçerlik türlerinin sorgulamasının yapılabilmesi amacıyla 32 adet madde hazırlanmıştır.

4. Hazırlanan 32 maddeden 12 'si bu aşamada diğer gruptaki maddelerle örtüşebileceği ve ölçeği daha kullanılışlı hale getirmek düşüncesiyle araştırmacı ve dil eğitimi veren 2 ayrı uzman akademisyen tarafından çıkarılmış ve ölçeğe ilk hali 20 madde olarak verilmiştir.

5. Maddelerin cevap karşıllıkları hazırlanırken araştırmanın odağında YDS olduğundan "Yabancı Dil Bilgisi Seviye Tespit Sinavı (YDS)" ibaresi bir soru kökü olarak belirlenmiş ve maddeler okunurken katılımcilara zaman kazandırmak adına ölçekteki bütün maddeler bu soru köküyle başlayan maddeler halinde düzenlenmiştir. Katılımcılara görüşlerini kolay ifade edebilmeleri amaciyla kesinlikle katılmıyorum, katılmıyorum, kısmen katıliyorum, kat1lyorum ve kesinlikle katıllyorum ibarelerinden oluşan 5’li Likert tipi bir ölçek hazırlanıp sunulmuştur.

6. Ölçek daha sonra araştırmacının da içinde olduğu 5 kişilik bir akademisyen grubu tarafından denenmiștir. Bu aşamada bütün soru köklerinde bulunan "Yabancı Dil Bilgisi Seviye Tespit Sınavı (YDS)" ibaresi gereksiz tekrara neden olduğundan ölçekte de maddelerin üzerinde yazılmasına karar verilmiş ve maddelerin içerikleri tekrar gözden geçirildiğinde "s1navdan düşük puan alan bir aday o dili yeterin- 
ce konuşamaz" yargısını içeren 1 madde daha atılmış ve YDS Geçerlik Tutum Ölçeği uzman görüşüne 19 madde olarak sunulmuştur.

7. Ölçek için uzman görüşü alımı iki aşamada yapılmıştır. Birinci aşamada YDS Geçerlik Tutum Ölçeği 3 ayrı üniversitede yabancı dil eğitimi veren fakültelerde çalışan 2 profesör, 2 doçent ve 2 yardımcı doçent doktordan oluşan 6 akademisyen tarafından incelenmiş ve maddeler üzerinde bazı değişiklikler yapılarak ölçek aynı sayıda maddeler içerecek şekilde onaylanmıştır. Sonraki etapta ölçek yine 3 farklı üniversiteden ölçme-değerlendirme, eğitim psikolojisi ve istatistik alanlarında çalışan 3 profesör, 2 doçent ve 2 yardımcı doçent doktordan oluşan 7 akademisyen tarafından incelenmiş ve bu süreç sonucunda ölçekten 2 madde daha atılmış ve kalan maddeler bazı değişiklikler yapılarak onaylanmıştır.

8. YDS Geçerlik Tutum Ölçeği daha sonra Türkçe yazım ve dilbilgisi için uzman görüşüne sunulmuş ve iki üniversiteden 1 doçent ve 1 yardımcı doçent doktordan oluşan 2 akademisyen tarafından incelenmiş, noktalama işaretleri ve kelime yazımlarıyla ilgili bazı değişiklikler yapılarak ölçeğe 17 madde olarak son hali verilmiştir. Ölçek için madde oluşturma, madde inceleme, alan bilgisi ve dil denetimi hususlarında toplam 33 akademisyenden uzman görüşü ve dönütü alınmıştır.

9. Ölçekle ilgili pilot çalışmalar yapabilmek amacıyla ilk etapta 5 ayrı devlet üniversitesinde çalişan 338 akademisyenden toplanan veri üzerinde Açıklayıcı ve Doğrulayıcı Faktör Analizi yapılmıştır. 338 kişiden toplanan verinin 167 kişilik bölümü açıklayıcı, 171 kişilik bölümünden toplanan veri ise doğrulayıcı faktör analizi için kullanılmıştır.

\section{YDS Geçerlik Tutum Ölçeği Faktör Analizi Sonuçları}

Açıklayıcı Faktör Analizinin başlıca amacı aralarında ilişki bulunduğu düşünülen çok sayıdaki değişken arasındaki ilişkilerin anlaşılmasını ve yorumlanmasını kolaylaştırmak için daha az sayıdaki temel boyuta indirgemek veya özetlemek olan bir grup çok değişkenli analiz tekniğinin işletilmesidir (Özdamar, 2013). Başka bir deyişle faktör analizi, aralarında ilişki bulunan çok sayıda değişkenden oluşan bir veri setine ait ilişki yapısının analiz edilip ortaya çıkarılarak araştırmacı tarafından veri setinde yer alan kavramlar arasındaki ilişkilerin daha kolay anlaşılmasına yardımcı olmaktadır. Doğrulayıcı faktör analiziyse analiz sonucunda elde edilen yapıyı açıklayıcı faktör analizinden elde edilen yapıyla karşılaştırma ve yapıların ne derece birbiriyle örtüştüğünü görme olanağ1 sağlar. Ölçeklerden elde edilen veriler analiz edilmiş ve elde edilen bulgular her iki ölçek için aşağıda ayrı ayrı verilmiştir. Doğrulayıcı faktör analiziyse analiz sonucunda elde edilen yapıyı açıklayıcı faktör analizinden elde edilen yapıyla karşılaştırma ve yapıların ne derece birbiriyle örtüştüğünü görme olanağı sağlar. Ölçeklerden elde edilen veriler analiz edilmiş ve elde edilen bulgular her iki ölçek için aşağıda ayrı ayrı verilmiştir. Doğrulayıcı faktör analiziyse analiz sonucunda elde edilen yapıyı açıklayıcı faktör analizinden elde edilen yapıyla karşılaştırma ve yapıların ne derece birbiriyle örtüştüğünü görme olanağı sağlar. Ölçekten elde edilen veriler analiz edilmiş ve elde edilen bulgular sunulmuştur.

Yapılan KMO ve Bartlett testlerinde YDS Geçerlik Tutum Ölçeği ile toplanan verinin faktör analizine uygun olduğu bulunmuştur. KMO değerinin. 835 çıkması faktörlenmek için verinin iyi olduğunu, Bartlett testi sonucunda elde edilen. 000 değeri de [ $\chi^{2}$ $=586,689 ; \mathrm{df}=66, \mathrm{p}<0.001]$ analizin yapılabileceğini gösterir. Ayrica yapılan Cronbach Alpha testinde ölçek (Cronbach Alpha = 0.821) güvenilir çıkmıştır.

Tablo 7. YDS Geçerlik Tutum Ölçeği KMO ve Bartlet Testi Sonuçları

\begin{tabular}{llr}
\hline & KMO ve Bartlet Testi & \\
Kaiser-Meyer-Olkin & & .835 \\
Örneklem Uygunluğu & Yaklaşık Ki-kare & 586.689 \\
\hline \multirow{3}{*}{ Bartlet Küresellik } & $\mathrm{sd}$ & 66 \\
& $\mathrm{p}$ & $\mathbf{0 0 1}$ \\
\hline
\end{tabular}


Tablo 9'da Ölçek için yapılan analiz sonucunda 3 faktör çıktığını yani YDS Geçerlik ölçeğinin üç alt boyutu olduğu belirlenmiş ve yapılan analizin veriden elde edilen varyansın \%55,852'lik bölümünü açıkladığ1 anlaşılmıştır. Büyüköztürk’e (2013) göre \%50 ve üstü açıklayıcılık değerleri açıklayıcı faktör analizi için kabul edilebilir oranlardır.

Tablo 8. YDS Geçerlik Tutum Ölçeği Faktör Analizi Sonuçları

\begin{tabular}{|c|c|c|c|c|c|c|c|c|c|}
\hline \multicolumn{10}{|c|}{ Toplam Açıklanan Varyans } \\
\hline \multirow[t]{2}{*}{ Bileşen } & \multicolumn{3}{|c|}{ Başlangıçtaki Özdeğerler } & \multicolumn{3}{|c|}{ Kareli Yükler Toplam Açılımı } & \multicolumn{3}{|c|}{ Kareli Yükler Toplamı } \\
\hline & Toplam & $\%$ Varyans & Bileşik \% & Toplam & $\%$ Varyans & Bileşik \% & Toplam & $\%$ Varyans & Bileşik \% \\
\hline 1 & 4.197 & 34.979 & 34.979 & 4.197 & 34.979 & 34.979 & 2.604 & 21.699 & 21.699 \\
\hline 2 & 1.393 & 11.610 & 46.589 & 1.393 & 11.610 & 46.589 & 2.336 & 19.466 & 41.165 \\
\hline 3 & 1.112 & 9.263 & 55.852 & 1.112 & 9.263 & 55.852 & 1.762 & 14.687 & 55.852 \\
\hline 4 & .991 & 8.258 & 64.110 & & & & & & \\
\hline 5 & .921 & 7.677 & 71.787 & & & & & & \\
\hline 6 & .774 & 6.446 & 78.233 & & & & & & \\
\hline 7 & .613 & 5.106 & 83.338 & & & & & & \\
\hline
\end{tabular}

Tablo 9'da verilen PCA analizine göre 0.300 den daha düșük değer alan 8,11 , 13nolu maddeler ile ayrı bir faktör oluşturan 4 ve 17nolu maddeler ölçekten çıkarılmıştır çünkü Özdamar (2013) bir faktörün açıklayıcı olabilmesi için en az 3 madde ile oluşturulması gerektiğini belirtmiştir. Birincil faktör yükü 0.398 den ve toplam korelasyon değeri 0,355 'ten daha düșük değildir ki bu değerler Özdamar’a (2013) göre kabul edilebilir değerlerdir.

\section{Tablo 9. YDS Geçerlik Tutum Ölçeği Faktör Yükleri}

\begin{tabular}{|c|c|c|c|c|c|}
\hline $\begin{array}{l}\text { Madde } \\
\text { No }\end{array}$ & $\begin{array}{c}\text { Başlangıç } \\
\text { faktör yükü } \\
\text { değeri }\end{array}$ & $\begin{array}{l}\text { Madde Toplam } \\
\text { Korelasyonu }\end{array}$ & $\begin{array}{l}\text { Madde } \\
\text { No }\end{array}$ & $\begin{array}{c}\text { Başlangıç } \\
\text { faktör yükü } \\
\text { değeri }\end{array}$ & $\begin{array}{c}\text { Madde Toplam } \\
\text { Korelasyonu }\end{array}$ \\
\hline $\mathrm{X} 1$ & 0.486 & 0.362 & X9 & 0.556 & 0.599 \\
\hline $\mathrm{X} 2$ & 0.467 & 0.355 & $X 10$ & 0.454 & 0.504 \\
\hline $\mathrm{X} 3$ & 0.523 & 0.607 & $\mathrm{X} 12$ & 0.673 & 0.709 \\
\hline $\mathrm{X} 5$ & 0.398 & 0.388 & $\mathrm{X} 14$ & 0.715 & 0.731 \\
\hline X6 & 0.472 & 0.549 & $\mathrm{X} 15$ & 0.475 & 0.556 \\
\hline $\mathrm{X} 7$ & 0.521 & 0.642 & $\mathrm{X} 16$ & 0.440 & 0.572 \\
\hline \multicolumn{6}{|c|}{ Açıklanan Varyans Miktarı 3 Faktör $=\mathbf{\%} \mathbf{5 5 , 8 5 2}$} \\
\hline \multicolumn{6}{|c|}{ Cronbach Alpha Değeri $=\mathbf{0 , 8 2 1}$} \\
\hline
\end{tabular}

Tablo 10'da Varimax Döndürme yöntemiyle yapılan döndürmeden sonra elde edilen 3 alt boyut ve boyutların içindeki maddeler verilmiştir.

Analizden elde edilen sonuçlara göre madde 2,1,5,6,3 YDS'deki soruların yabancı dil ölçmek için ne denli elverişli olduğunu ve sınavın içeriğinin bir dil sınavina uygunluğunu sorguladığından ölçeğin birinci alt boyutu olan YDS’nin Kapsam Geçerliğini oluşturduğuna karar verilmiş ve bu maddeler analizden sonra oluşturulan ölçekte sırasılyla madde $1,4,7,10,12$ olarak yeniden numaralandırılmıştır. Madde 9,16,15,10 YDS’nin başka dil sınavlarıyla eşdeğerliği ve akademisyenlerin bu sınavı geçmesi kriteriyle ilgili bulunduğundan ölçeğin ikinci alt boyutu olan YDS’nin Kriter Geçerliğiini oluşturduğuna karar verilmiş ve bu 
Tablo 10. YDS Geçerlik Tutum Ölçeği Alt Boyutlar

\begin{tabular}{lccc}
\hline & \multicolumn{3}{c}{ Bileşen } \\
\cline { 2 - 4 } & 1 & 2 & 3 \\
\hline YDS - GEÇERLIK 2 & .840 & & \\
YDS - GEÇERLIK 1 & .669 & & \\
YDS - GEÇERLIK 5 & .643 & & \\
YDS - GEÇERLIK 6 & .599 & & \\
YDS - GEÇERLIK 3 & .557 & & \\
YDS - GEÇERLIK 9 & & .750 & \\
YDS - GEÇERLIK 16 & & .740 & \\
YDS - GEÇERLIK 15 & & .699 & .841 \\
YDS - GEÇERLIK 10 & & .556 & .601 \\
YDS - GEÇERLIK 12 & & & \\
YDS - GEÇERLIK 7 & & & \\
YDS - GEÇERLIK 14 & & & \\
\hline
\end{tabular}

maddeler analizden sonra olușturulan ölçekte madde 2,5,8,11 olarak yeniden numaralandırılmıştır. Madde 12,7,14 YDS'den elde edilen notların yabancı dil bilgisi yeterliğini ne ölçüde yansıttığını sorguladığından ölçeğin üçüncü alt boyutu olan YDS Sonuçlar1nın Yordamlayıcılığı'nı oluşturduğuna karar verilmiș ve bu maddeler analizden sonra olușturulan ölçekte madde 3,6,9 olarak yeniden numaralandırılmıştır. Açıklayıcı faktör analizinden elde edilen yapının doğrulanması amacıyla 3 ayrı devlet üniversitesinde çalışan 171 akademisyenden toplanan veri üzerinde Doğrulayıcı Faktör Analizi (Confirmatory Factor Analysis (CFA)) yapılmıştır. Şekil 1'de elde edilen yapı verilmiştir.

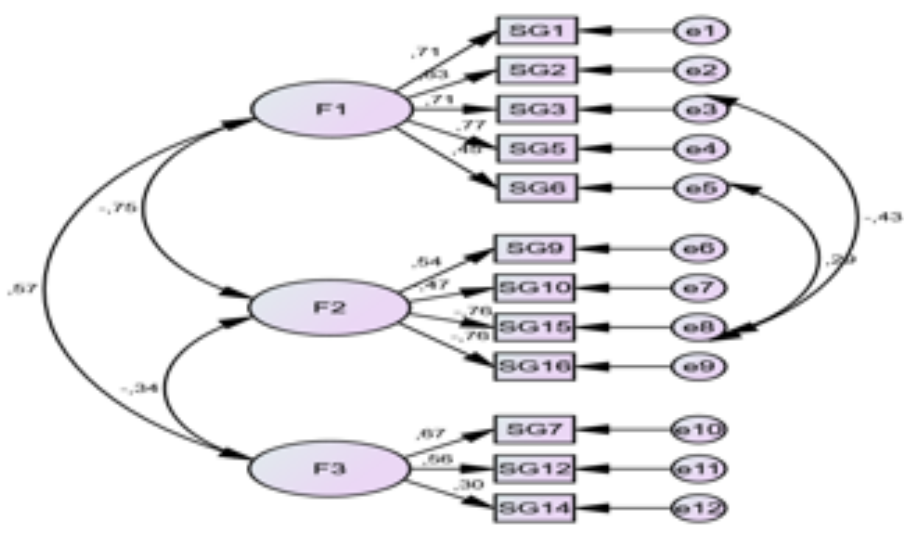

Şekil 1. YDS Geçerlik Tutum Ölçeği Doğrulayıcı Faktör Analizi

Şekil 1'de F1 olarak görünen faktör YDS'nin Kapsam Geçerliği’ni, F2 olarak görünen faktör YDS'nin Kriter Geçerliğiini ve F3 olarak görünen faktör ise YDS Sonuçlarının Yordamlayıcılığı’nı temsil etmektedir.
Doğrulayıcı faktör analizinden elde edilen Ki kare ve serbestlik dereceleri $\left(\chi^{2}=95.662,(\mathrm{df}=49, \mathrm{p}<0.001)\right.$ ve $\left(\chi^{2} / \mathrm{df}=1,952\right)$ oranına bakıldığında $1,952^{\prime}$ lik bir oran Jöreskog ve Sörbom (1993), Kline (2005) ve Sümer 
(2000)'e göre 3.00 değerinin altında çıktığından çok iyi bir eşleşme olarak yorumlanır. Tablo 8'de YDS Geçerlik Tutum Ölçeği için yapılan Doğrulayıcı Faktör Analizinin yorumu için gerekli olan değerler verilmiştir.
Yapılan analizde RMSEA değeri 0,057 çıkmıştır ve bu değer pek çok uzmana göre 0,08 değerinden düşük olduğundan iyi bir örtüşme olduğunu gösterir (Browne ve Cudeck, 1993; Hu ve Bentler, 1999; Şimşek, 2007; Vieira, 2011). AGFI ve RMR değerle-

Tablo 12. YDS Geçerlik Tutum Ölçeği DFA'dan Elde Edilen Örtüşme Düzeyi

\begin{tabular}{lllllll}
\hline$\chi^{2}$ & $\mathrm{D}_{\mathrm{f}}$ & $\chi^{2} / \mathrm{D}_{\mathrm{f}}$ & RMSEA & AGFI & RMR & CFI \\
\hline 95.662 & 49 & 1.952 & 0.057 & 0.877 & 0.036 & 0.963 \\
\hline
\end{tabular}

ri yine uzmanlara göre (Anderson ve Gerbing, 1984; Marsh, Balla ve McDonald, 1988) kontrol edilmesi gereken değerler olup AGFI için 0,8 'den büyük değerler, RMR içinse 0,10 'dan küçük değerler yapıyı doğrulama için gereklidir. Verinin analizinden elde edilen sonuçlar AGFI için 0.8 den büyük $(0,8<0,877)$ RMR için 0,10 'dan küçük $(0,036<0,10)$ olduğu için yapının doğrulandığını gösterir. Son olarak $\mathrm{Hu}$ ve Bentler (1999), Sümer (2000) ve Şimşek’e (2007) göre CFI değeri 0,95 ve üstü çıkmışsa bu mükemmel uyum ve doğrulamayı gösterir. Veriden elde edilen 0,963'lük CFI değeri yapının doğrulandığını bir kez daha kanttlar niteliktedir.

Sonuç olarak YDS’nin geçerliğine ilişkin veri toplama amacıyla hazırlanan YDS Geçerlik Tutum Ölçeğinin Açıklayıcı Faktör Analizi sonuçlarına göre ölçek güvenilir bir ölçek çıkmış (Cronbach Alpha $=0.821)$, ölçekte YDS'nin Kapsam Geçerliği, YDS'nin Kriter Geçerliği ve YDS Sonuçlarının Yordamlayıcılı̆̆ı olarak isimlendirilen üç alt boyut tespit edilmiştir. YDS Geçerlik Tutum Ölçeğinin Doğrulayıcı Faktör Analizi sonuçları da Açıklayıcı Faktör Analizi sonuçlarıyla örtüşür biçimde çıkmış ve ölçekte ortaya çıan yapı istatistiksel olarak doğrulanmıştır. YDS'nin geçerliği ile ilgili belirlenen alt boyutlardan YDS'nin Kapsam Geçerliği sınavın ölçme amacına uygunluğu ile ilgili maddelerden oluşurken, YDS’nin Kriter Geçerliği YDS'nin başka dil sınavlarılya olan benzer ya da fark11 yönlerini belirleyen maddelerden oluşmuştur. 3. ve son alt boyut olan YDS Sonuçlarının Yordamlayıcılığı ise sınavdan elde edilen sonuçların dil yeterliğini ne ölçüde doğru yansittığg ve bu sonuçlardan hareketle ne gibi kararlar alınabileceğiyle alâkalıdır. Alt boyutlara verilen isimler araştırmacının ilgili maddeleri inceleyen uzmanlardan görüş alarak belirlediği isimlerdir, testler için kullanılan geçerlik türleri ile birbirine karıştırılmaması gerekir. Ölçek geliştirme sürecinden elde edilen verilerin ölçek geliştirildikten sonra toplanan verilerle de sağlaması yapılmıştır. İlk olarak faktörleme için yapılan KMO ve Bartlett testlerinde $\mathrm{KMO}$ değeri $=809$ bulunurken sonrasında yapılan Faktör anaizinde Açıklanan Varyans Miktarı 3 Faktör $=\%$ 52,211, Cronbach Alpha Değeri $=0,793$ bulunmuştur. Tüm veri elde edildikten sonra yapılan doğrulayıcı faktör analizi değerleri de örtüşme düzeyinin kabul edilen değerler içerisinde olduğunu göstermiş (RMSEA = 0,61; AGFI=0,823; RMR=0,33; $\mathrm{CFI}=0,909)$ ve ortaya çıkan yapının güvenirliği ve örtüşme düzeyi bir miktar azalsa da kabul edilir sınırlar içerisinde olduğu görülmüştür.

\section{Bulgular}

Türkiye'deki devlet üniversitelerinde görev yapan akademisyenlerin yabancı dil yeterlik ölçümünde kullanılan YDS'nin geçerliğiyle ilgili tutumlarının belirlenmesi amaçlanan bu çalışmadan derlenen veriler üzerinde yapılan kümeleme analizleri sonucunda elde edilen histogram grafikleri alt boyutlar halinde ve faktör boyutuna göre sırasıyla verilmiştir. 


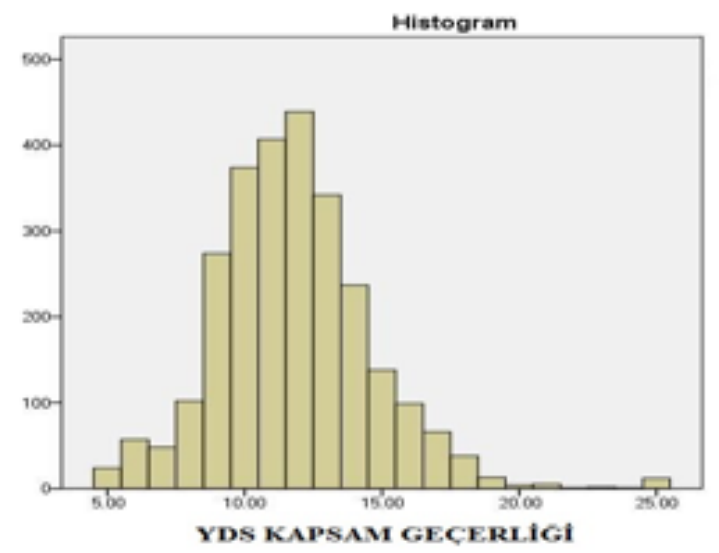

Şekil 2. YDS Kapsam Geçerliği Histogram Grafiği

Akademisyenlerin YDS’nin Kapsam Geçerliği alt boyutu içerisinde yer alan beş maddeye verdikleri cevapların ortalamaları Şekil 2'de verilmiştir. Ölçekte yer alan her bir madde beşli Likert ölçeğiyle sorulduğundan ve adı geçen faktörde toplam 5 madde yer aldığından 5-25 puanlık bir değer aralığı elde edilmiştir. Ölçekte yer alan ilk iki değerin "kesinlikle katılmıyorum ve katılmıyorum" olduğu hatırlandığında şekilde karşımıza çıkan bulgu çalışmaya katılan akademisyenlerin YDS’nin kapsam geçerliğiyle ilgili ifadelere (YDS yabancı dil seviyesini ölçebilen bir sınav- dır, soruları Türkiye'de edinilmesi istenilen yabancı dil becerilerinin ölçümüne uygundur vb.) çoğunlukla katılmadıklarını gösterebilir. Ortalama bazında elde edilen $\bar{X}=1,88(9,4 / 5=1,88)$ değeri de bu bulguyu destekler niteliktedir. Diğer taraftan ilgili maddelere katıldığını veya kesinlikle katıldığını belirten akademisyenlerin oranı oldukça düşük $(\% 4,2)$ çıkmıştır. Ortaya çıkan bu tablo akademisyenlerin YDS'nin yabancı dil ölçme de geçerliğiyle ilgili ağılıklı olarak olumsuz görüşlere sahip olduğunu göstermektedir.

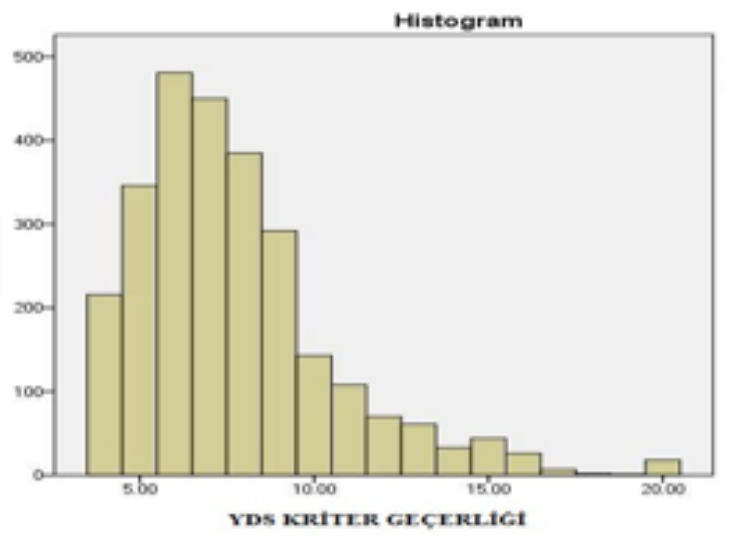

Şekil 3. YDS Kriter Geçerliği Histogram Grafiği 
YDS Kriter Geçerliği alt boyutuna baktığımızda katılımcıların verdikleri yanıtlar açısından çok daha net bir tablo karşımıza çıkıyor. Şekil 3’te verilen YDS Kriter Geçerliği alt boyutunda yer alan maddelere (YDS puanı uluslararası geçerli herhangi başka bir yabancı dil testinden alınan dil yeterlilik puanı ile benzer çıkacaktır, puanı yabancı dil seviyesi ile ilgili alınacak kararlarda tek başına geçerli olmalıdır vb.) verdikleri cevaplara bakıldığında katılımcı akademisyenlerin söz konusu ifadelere çoğunlukla hiç katılmadıkları görülebilir. YDS Kapsam geçerliğinde olduğu gibi Kriter Geçerliği alt boyutunda da akademisyenlerin sınavın kriter geçerliğiyle ilgili olumsuz görüşlere sahip oldukları belirlenmiştir. Ortalama bazında elde edilen $\overline{\mathrm{X}}=1,92(7,70 / 4=1,92)$ değeri de bu bulguyu destekler niteliktedir.

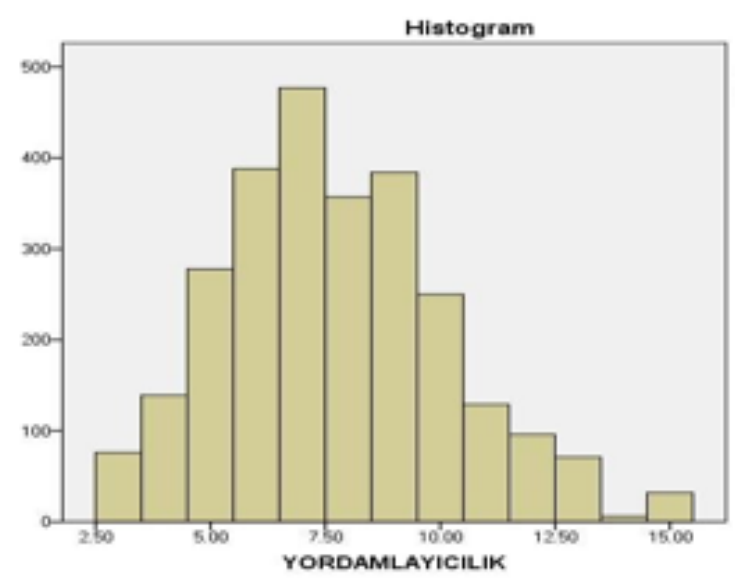

Şekil 4. YDS Yordamlama Histogram Grafiği

Şekil 4’te verilen Yordamlama alt boyutunda yer alan maddelere (YDS sorularını çözebilmek için o yabanc1 dili iyi bilmek yeterlidir, yabancı dili yurtdışında yaşayarak veya bir süreliğine kalarak öğrenmiş adaylar için kolaydır, sonunda 90 ve üstü alan bir aday o yabancı dili ileri düzeyde kullanabilir) verdikleri cevaplara bakıldığında daha normal bir dağılımdan bahsederken, katılımcı akademisyenlerin söz konusu ifadelere daha ziyade kısmen katılma yönünde yanıtlar verdiklerini söyleyebiliriz. Ortalama bazında elde edilen $\overline{\mathbf{X}}=2,53(7,70 / 3=2,53)$ değeri de bu bulguyu destekler niteliktedir.

Şekil 5'te katılımcıların unvanları ve YDS'den aldıkları son notları çok boyutlu analiz yöntemiyle gösterilmiştir. Çok boyutlu analiz, katılımcıların araştırma konusuyla ilgili bazı özelliklerinin (unvan, YDS skoru vs.) bir araya getirilerek sanal dilimler üzerinde, verilerin ortalamaları bazında ilişkiler kurulmasına yardımcı olabilir. 


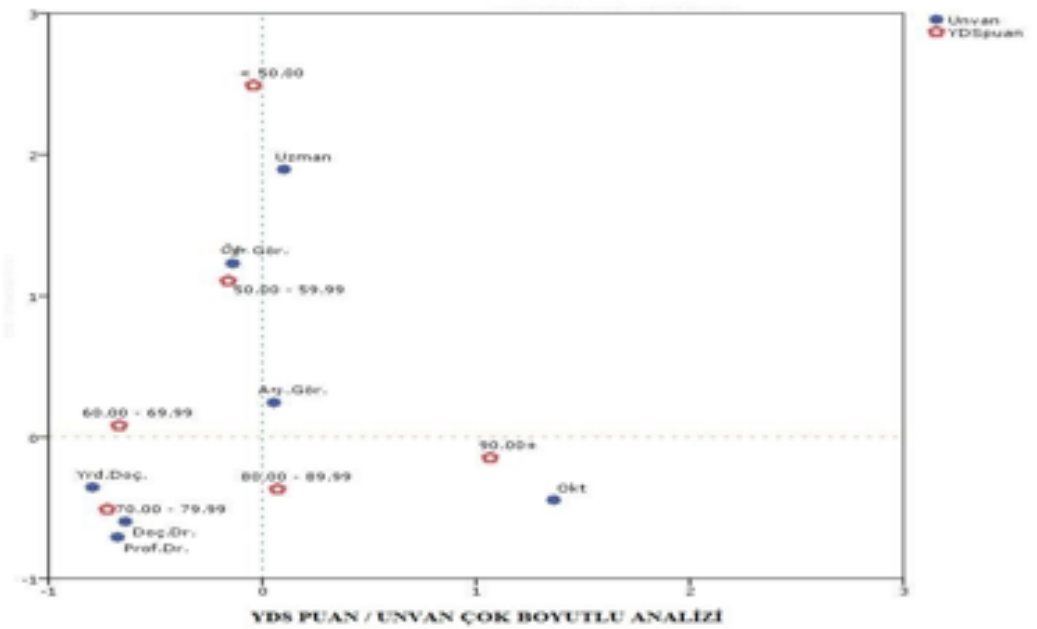

Şekil 5. Katılımcıların Unvanları ve YDS Skorlarının Çok Boyutlu Analizi

$\mathrm{Bu}$ analizde kümelendiği takdirde akademisyenlerin aldığı skorlar ve unvanlarının boyutlar halinde nasıl ayrışabilecekleri incelenmiş ve elde edilen sonuçlar görselleştirilmiştir. Katılımcılardan YDS'den 50-59 puan aralığında not alanların çoğunlukla uzman, öğretim görevlisi ve kısmen araştırma görevlileri olduğu, 60-69 puan aralığındaki kadroların genellikle araştırma görevlileri ve kısmen yardımcı doçent kadrolarının olduğu, 70-79 puan aralığında not alanların yardımcı doçent, doçent ve profesörler olduğu ve 90 puan ve üstü not alanların ise genellikle okutman kadrosuna sahip akademisyenler olduğu belirlenmiştir. Çalışmada yer alan okutmanların tamamının yabancı dil eğitimi veren okutmanlar olduğu, öğretim görevlisi ve uzmanların ise yabancı dil eğitimcileri olmadıkları hatırlandığında elde edilen sonuçlar oldukça anlamlıdır. Ortaya çıkan bu durum çalışmaya katılan akademisyenlerle ilgili 3 tabaka ortaya çıktığını göstermiştir. Birinci tabakayı YDS'den 90 puan civarında notlar alan akademisyenler oluşturmaktadır ki analiz sonuçlarına göre bu puan seviyesine yaklaşan tek grup okutmanlar olmuştur. Hatırlanmalıdır ki çalışmaya katılan okutmanların tamamı dil eğitimcilerinden oluşturulmuştur ve bu durum da okutman kadrosunun neden bu kadar yüksek notlar aldığını açıklar. İkinci tabakayı 60-80 puan arasında skorlar alan akademisyenler oluşturmaktadır ki bu grupta da profesör, doçent, yardımcı doçent ve araştırma görev- lilerinin yer aldığ 1 görülmektedir. Bu grupta yer alan akademisyenlerin lisansüstü eğitim ve kadro almaları için gereken 65-70 civarı puanları almaları dil yeterliği anlamında kendilerini ispat anlamına geleceğinden sayılan unvanların bu puan marjı arasında yer almalarının nedeni şeklinde düşünülebilir.

Araştırmada akademisyenlerin YDS ile ilgili görüşlerine etki edebileceği etkenler arasında yer alabileceği düşünülen cinsiyet, medeni durum, YDS'den alınan en son puan, akademik unvan, ve YDS’ye giriş nedeni gibi bağımsız değişkenler ölçekte yer alan faktörler bazında incelenmiştir. İlk olarak cinsiyet görüşlerde fark yaratıyor mu sorusunun cevabına bakıldığında kadın ve erkek akademisyenlerden elde edilen veri incelendiğinde, ölçekte yer alan 3 alt boyutun hiçbirinde anlamlı fark çıkmamıştır $(\mathrm{p}<0.05)$. Bu sonuçtan hareketle verilen cevapların kadın-erkek katılımcılar arasında önemli bir fark yaratmadığı söylenebilir.

Evli akademisyenlerin YDS'ye hazırlanmakta ve yabancı dile zaman ayırmakta daha fazla sıkıntı yaşadığı düşünülür. Ancak çalışmadan elde edilen sonuçlar bu yargının doğru olmadığını gösterir niteliktedir. Katılımcıların medeni durumlarının görüşlerinde anlamlı bir fark yaratıp yaratmadığ 1 analiz edildiğinde evli veya bekâr katılımcıların cevapları arasında anlamlı farklar bulunmadığı $(\mathrm{p}<0.05)$ ortaya çıkmıştır. 
Veriler üzerinde yapılan analizlerde ilk olarak çalışmaya katılan akademisyenlerin YDS puanları dikkate alınmış ve ölçekteki sorulara verdikleri yanıtların ortalamalarının varyans analizi sonuçlarına bakıldığında akademisyen görüşlerinin YDS'den aldıkları puanlara göre anlamlı farklılıklar gösterdiği bulunmuştur $(\mathrm{p}<0.05)$. Bu durumda YDS'den alınan puanların katılımcıların cevaplarını önemli ölçüde etkilediğini söyleyebiliriz. Bu analizden hareketle hangi grupların ortalamaları arasında fark olduğunu belirleyebilmek amacıyla Tablo 9'da verilen Tamhane çoklu karşılaştırma testi (grupların varyansları homojen çıkmadığından Tamhane testi tercih edilmiş ve tabloda anlamlılık düzeyleri özetlenmiştir) yapılmıştır.

Bilindiği üzere tek yönlü varyans analizi, bir faktör çatısı altında, iki ya da ikiden daha fazla bağımsız grubun ortalamalarını karşılaştırmak için kullanılır. Tek yönlü varyans analizinde iki temel varsayım vardır. Her grup normal dağılımlıdır ve göreceli olarak grupların varyansları homojendir. Fakat varyanslar homojen değilse uygulanacak istatistiksel testler farklılık gösterir. Çünkü hatırlanacağ 1 üzere tek yönlü varyans analizi, bir faktör çatısı altında, iki ya da ikiden daha fazla bağımsız grubun ortalamalarını karşılaştırmak için kullanılır. Tek yönlü varyans analizinde iki temel varsayım vardır. Her grup normal dağılımlıdır ve göreceli olarak grupların varyansları homojendir. Ancak varyanslar homojen değilse uygulanacak istatistiksel testler farklılık gösterir. Tablo 13'te katılımcıların YDS puanları dikkate alınarak verdikleri yanıtların ortalamalarının varyans analizi öncesi Homojenlik testi verilmiş ve ölçeklerin tüm boyutlarında anlamlı fark çıkmıştır $(\mathrm{p}<0.05)$. Bu durumda grupların varyansları homojen değildir. $\mathrm{Bu}$ nedenle uygulanacak testler ve istatiksel yöntem bu durum dikkate alınarak seçilmiştir.

Tablo 13. Homojenlik Testi

\begin{tabular}{lrrrrr}
\hline Varyansların Homojenliği Testi & & & \\
\hline & $\begin{array}{c}\text { Levene } \\
\text { İstatistiği }\end{array}$ & sd 1 & sd2 & $\mathrm{p}$ \\
YDS Kapsam Geçerliği & 6.849 & 2 & 2677 & .001 \\
YDS Kriter Geçerliği & 10.108 & 2 & 2677 & .001 \\
YDS Yordamlama & 18.854 & 2 & 2677 & .001 \\
& & & & \\
\hline
\end{tabular}

Bir sonraki analizde akademisyenlerin YDS puanları dikkate alınarak ölçekteki sorulara verdikleri yanıtların ortalamalarının varyans analizi sonuçları alınmıştır. Akademisyen görüşlerinin YDS'den aldıkları puanlara göre ölçeğin bütün alt boyutlarında anlamlı farklılık gösterdiği bulunmuştur $(\mathrm{p}<0,05)$. $\mathrm{Bu}$ durumda YDS'den alınan puanların katılımciların cevaplarını etkilediğini söyleyebiliriz. Daha çok puan alanların mı yoksa daha az alanların mı farklılık yarattı̆̆ının tespiti ve karşılaştırılmaların görülmesi amacıyla çoklu karşılaştırma testlerine ihtiyaç duyulmuştur. Bu sebeple hangi grupların ortalamaları arasinda fark olduğunu belirleyebilmek amaciyla Tablo 14 'te verilen Tamhane çoklu karşılaştırma testi (grupların varyansları homojen çıkmadığından Tamhane uygulanmıştır) yapılmıştır. 
Tablo 14. YDS Puanına Göre Yapılan Çoklu Karşılaştırmalar

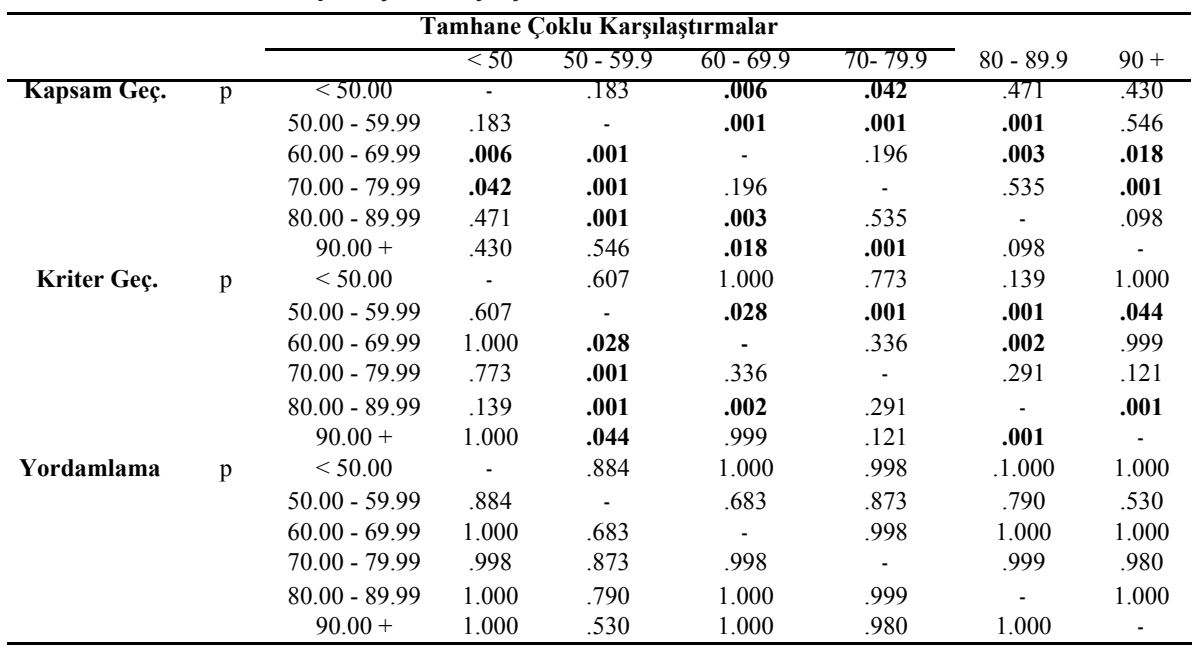

Akademisyenlerin ölçekte yer alan sorulara verdikleri cevaplar arasındaki ilişkiye bakıldığında YDS Kapsam Geçerliği alt boyutunda YDS'den 60 puanın altında alan katılımciların verdikleri cevaplarla 90 puan ve üzeri notlar alan katılımciların cevaplarının ortalamaları arasında anlamlı bir fark çıkmazken 60-80 puan aralığında notlar alan katılımcıların verdikleri cevaplarla aralarında anlamlı fark çıkmıştır $(\mathrm{p}<0.05)$. $\mathrm{Bu}$ durum aslında yabancı dil yeterliği açısından en iyi ve en kötü olmak üzere uçlarda olan iki grubun sınavın geçerliğine ilişkin görüşlerinin benzer olduğunu ortaya koymuştur. Öte yandan sınavdan 60-80 arası notlar alan katılımciların cevaplarının alt ve üst puan alan gruplardan farklılaşmasının nedeni düşünüldüğünde YDS’nin 60-80 puan alan grup için farklı anlam taşıdığı ve bu nedenle geçerliğiyle ilgili düşüncelerin değişebildiği söylenebilir. Kriter geçerliği alt boyutuna bakıldığında 50-60 puan aralığında notlar alan katılımcıların en farklı cevaplar veren katılımcı grubu olduğu göze çarpmaktadır. Bu grup diğer taraftan \%11 ile adayların YDS dışında geçerliği kabul gören uluslararası dil sinavlarına girme yüzdesiyle diğer puan aralıkları arasında en üstte yer almaktadır, başka sınavlara en az giren grup ise $\% 1$ ile 50 puanın altında alan grup olmuştur. 50-60 puan aralığında notlar alan katılımcıların neden farklı sınavlara diğer

Tablo 15. Unvanlara Göre Yapılan Çoklu Karşılaştırmalar

\begin{tabular}{|c|c|c|c|c|c|c|c|c|c|}
\hline \multicolumn{10}{|c|}{ Tamhane Çoklu Karşılaştırmalar } \\
\hline & & & Uzm. & Okutman & Öğr. Gör. & Arș. Gör & Yrd. Doc. & Doc. Dr. & Prof. \\
\hline \multirow[t]{7}{*}{ Kapsam Geç. } & \multirow[t]{7}{*}{$\mathrm{p}$} & Uzman & - & .001 & 1.000 & .012 & .005 & .001 & .001 \\
\hline & & Okutman & .001 & - & .001 & .001 & .001 & .004 & .001 \\
\hline & & Öğr. Gör. & 1.000 & .001 & - & .001 & .001 & .001 & .001 \\
\hline & & Arş. Gör & .012 & .001 & .001 & - & 1.000 & 1.000 & .001 \\
\hline & & Yrd. Doç. & .005 & .001 & .001 & 1.000 & - & .914 & .001 \\
\hline & & Doç. Dr. & .001 & .004 & .001 & 1.000 & .914 & - & .001 \\
\hline & & Prof. Dr. & .001 & .001 & .001 & .001 & .001 & .001 & - \\
\hline \multirow[t]{7}{*}{ Kriter Geç. } & \multirow[t]{7}{*}{$\mathrm{p}$} & Uzman & - & .009 & 1.000 & 1.000 & 1.000 & 1.000 & .001 \\
\hline & & Okutman & .009 & - & .001 & .034 & .005 & .098 & .771 \\
\hline & & Öğr. Gör. & 1.000 & .001 & - & .915 & .426 & .771 & .001 \\
\hline & & Arş. Gör & 1.000 & .034 & .915 & - & 1.000 & 1.000 & .001 \\
\hline & & Yrd. Doç. & 1.000 & .005 & .426 & 1.000 & - & 1.000 & .001 \\
\hline & & Doç. Dr. & 1.000 & .098 & .771 & 1.000 & 1.000 & - & .001 \\
\hline & & Prof. Dr. & .001 & .771 & .001 & .001 & .001 & .001 & - \\
\hline \multirow[t]{7}{*}{ Yordamlama } & \multirow{7}{*}{$\mathrm{p}$} & Uzman & - & .008 & .001 & .001 & .001 & .001 & .022 \\
\hline & & Okutman & .008 & - & .006 & .001 & .001 & .932 & 1.000 \\
\hline & & Öğr. Gör. & .001 & .006 & - & .142 & .019 & 1.000 & 1.000 \\
\hline & & Arş. Gör & .001 & .001 & .142 & - & .998 & .748 & .132 \\
\hline & & Yrd. Doç. & .001 & .001 & .019 & .998 & - & .300 & .186 \\
\hline & & Doç. Dr. & .001 & .932 & 1.000 & .748 & .300 & - & 1.000 \\
\hline & & Prof. Dr. & .022 & 1.000 & 1.000 & .132 & .186 & 1.000 & - \\
\hline
\end{tabular}


katılımcılara nazaran daha fazla girdiği düşünüldügünde Türkiye'de birçok kurumun yabancı dil yeterlik için istedikleri 65-70 civarı notların etkili olduğu ve katılımcıların doğal olarak bu notları alabilmek adına şanslarını başka dil sınavlarında denemek isteyebilecekleri de söylenebilir. YDS Yordamlama alt boyutu ele alındığında ise katılımcıların cevaplarının ortalamaları arasında anlamlı fark çıkmamıştır $(\mathrm{p}<0.05)$. $\mathrm{Bu}$ sonuçtan hareketle katılımcıların YDS'nin yordamlayıcıllğ 1 konusunda farklı düşünceler ortaya koymadıkları söylenebilir.

Bağımsız değişken olarak katılımcıların unvanları ele alınmış ve ölçekteki sorulara verilen yanıtların ortalamalarının varyans analizi sonuçlarına bakıldığında akademisyen görüşlerinin unvanlarına göre anlamlı farklılıklar gösterdiği bulunmuştur $(\mathrm{p}<0.05)$. $\mathrm{Bu}$ durumda akademik unvanlarının katılımcıların cevaplarını önemli ölçüde etkilediğini söyleyebiliriz. $\mathrm{Bu}$ analizden hareketle hangi grupların ortalamalar1 arasında fark olduğunu belirleyebilmek amacıyla Tablo 15'te verilen Tamhane çoklu karşılaştırma testi yapılmıștır.

Akademisyenlerin ölçekte yer alan alt boyutlardaki sorulara verdikleri cevaplar arasındaki ilişkiye bakıldığında YDS Kapsam Geçerliği alt boyutunda öğretim görevlisi ve uzmanların verdikleri yanıtların aralarında istatistiksel olarak bir fark görülmezken diğer tüm akademik kadrolardan anlamlı bir biçimde ayrıldıkları görülebilir $(p<0.05)$. Öte taraftan okutmanların ve profesörlerin kapsam geçerliği bağlamında diğer akademisyenlerden farklı cevaplar verdikleri ve bu alt boyuttaki maddelere ilişkin birbirleriyle benzer $(\mathrm{r}=, 603)$ ama diğer kadrolarla karşılaştırıldıklarında farklı davrandıkları bulunmuştur $(\mathrm{p}<0.05)$. Okut- manların YDS konusundaki farklı görüşlerinin altında dil tecrübelerinin yattığı düşünülebilir, farklı ortamlarda farklı sınavlara girmiş olmaları onları YDS konusunda kritik yapabilecek, söz sahibi olabilecek tecrübe ve yetkinliğe getirmiş olabilir. Bu yetkinlikte farklı davranmalarının sebebi olarak düşünülebilir. Profesörlerin ise diğer akademisyenlere göre çok daha tecrübeli olmaları ve dil yetkinliği ile ilgili Türkiye'deki tabloya daha fazla aşina olmaları YDS konusunda kapsam geçerliği ile ilgili maddelere ilişkin diğer katılımcılardan daha farklı davranmalarının sebebi olarak açıklanabilir. Ayrıca unutulmaması gereken bir diğer faktörde Profesörlerin dil yeterliğiyle ilgili artık bir dertlerinin olmadığ 1 ve bu olguya bu sayede uzaktan bakabilmeleridir. Söz konusu alt boyutta doçent, yardımcı doçent ve araştırma görevlilerinin cevapları arasında anlamlı fark çıkmazken bu grubun (ki bu unvanlara sahip akademisyenler YDS puanı bazında orta grupta yer almışlardı) okutman, profesör, ögretim görevlisi ve uzmanlardan istatistiksel olarak farklı davrandıkları belirlenmiştir $(\mathrm{p}<0.05)$. YDS Kriter Geçerliği alt boyutunda da benzer bir tablo ortaya çıkmıştır, yine okutmanlar ve profesörler birbirleriyle benzer cevaplar verirken $(r=, 812)$ diğer kadrolardan anlamlı düzeyde farklı davranmışlardır $(\mathrm{p}<0.05)$. Gerek Kapsam Geçerliği gerek Kriter Geçerliği alt boyutlarında ortaya çıkan bu belirgin farklılık teknik açıdan sınavla ilgili en belirleyici yorumları yapabilecek iki akademik grubun benzer cevaplar verdiği ve histogram grafikleri hatırlandığında YDS’nin kapsam ve kriter geçerliği ile ilgili maddelere verilen cevaplarda ortaya çıkan negatif tutum hatırlandığında sınavla ilgili ortak kanıyı da ortaya koyabilir. YDS'nin Yordamlayıcılığı Alt boyutunda ise özellikle uzmanların verdiği yanttların diğer akademisyenlerden belirgin biçimde farklılık gösterdiğini söyleyebiliriz $(\mathrm{p}<0.05)$.

Tablo 16. Çalışma Alanı Çoklu Karşılaştırmalar

\begin{tabular}{|c|c|c|c|c|c|c|c|}
\hline & & \multicolumn{4}{|c|}{ Tamhane Coklu Karșılaștırmalar } & \multirow[b]{2}{*}{ Eğitim } & \multirow[b]{2}{*}{ Diğer } \\
\hline & & & Sosyal & Fen Bil. & Sağlık & & \\
\hline \multirow[t]{5}{*}{ Kapsam Geç. } & $\mathrm{p}$ & Sosyal Bil. & - & .001 & .203 & 1.000 & .008 \\
\hline & & Fen Bil. & .001 & - & 1.000 & .001 & 1.000 \\
\hline & & Sağlık Bil. & .203 & 1.000 & - & .212 & 1.000 \\
\hline & & Eğitim Bil. & 1.000 & .001 & .212 & - & .006 \\
\hline & & Diğer & .008 & 1.000 & 1.000 & .006 & - \\
\hline \multirow[t]{5}{*}{ Kriter Geç. } & $\mathrm{p}$ & Sosyal Bil. & - & .001 & .989 & .019 & 1.000 \\
\hline & & Fen Bil. & .001 & - & .602 & .001 & .007 \\
\hline & & Sağlık Bil. & .989 & .602 & - & .039 & .966 \\
\hline & & Eğitim Bil. & .019 & .001 & .039 & - & .014 \\
\hline & & Diğer & 1.000 & .007 & .966 & .014 & - \\
\hline \multirow[t]{5}{*}{ Yordamlama } & $\mathrm{p}$ & Sosyal Bil. & - & 1.000 & .962 & .155 & .182 \\
\hline & & Fen Bil. & 1.000 & - & .969 & .220 & .224 \\
\hline & & Sağlık Bil. & .962 & .969 & - & 1.000 & .999 \\
\hline & & Egitim Bil. & .155 & .220 & 1.000 & - & 1.000 \\
\hline & & Diğer & .182 & .224 & .999 & 1.000 & - \\
\hline
\end{tabular}


Bir sonraki analizde bu defa katılımcıların çalışma alanları ana başlıklar hâlinde bağımsız değișken olarak alınarak ölçekteki maddelere verdikleri cevaplara etkisi incelenecektir.

Akademisyenlerin ölçekte yer alan alt boyutlarda yer alan sorulara verdikleri cevaplar arasındaki ilişkiye bakıldığında YDS Kapsam Geçerliği alt boyutunda sosyal bilimler alanındaki akademisyenlerle fen bilimleri alanındaki ve diğer bilimler (bu başlık altında güzel sanatlar, iletişim bilimleri, ulaştırma bilimleri, havacılık ve uzay bilimleri vs. yer almıştır) başlığı altındaki akademisyenler arasında anlamlı fark göze çarpmaktadır $(\mathrm{p}<0.05)$. Özellikle fen bilimlerinde çalışan akademisyenlerin sosyal bilimciler ve eğitimcilerle karşılaştırıldıklarında farklı davranmış olmaları onların yabancı dil eğitimi ve ölçümünü farklı algılıyor olabileceklerini gösterebilir. Eğitimciler ve sosyal bilimciler arasında fark çıkmaması ve aralarında pozitif yönde bir korelasyon çıkması da $(\mathrm{r}=.503)$ bu iki alandaki akademisyenlerin yabancı dil değerlendirmesi ile ilgili benzer bir algıya sahip olduklarını gösterir. Mülakat yapılan katılımcılar da benzer sonuçlara varmışlardır. YDS Kriter geçerliği alt boyutunda ise eğitimcilerin verdikleri cevapların diğer tüm alanlara göre anlamlı farklılık gösterdiğini $(p<0.05)$ görüyoruz. Bu belirgin farklılığın nedeni de eğitimcilerin ölçme değerlendirme konusunda diğer alanlara göre daha tecrübeli olmaları gösterilebilir. YDS’nin Yordama geçerliği alt boyutunda yer alan sınav sonuçlarının yabancı dil becerilerini gerçekçi bir şekilde yansıtıp yansitmadığı ile ilgili maddelere ortalamalar bazında en düşük yanıtları veren akademisyenlerin eğitim bilimlerinden olduğunun hatırlanması da eğitimcilerin bu konuda neden ayrıştığını açıklayabilir.

$\mathrm{Bu}$ bölümde sunulacak son analizde bağımsız değişken olarak katılımcıların YDS'ye giriș nedenleri ele alınmış ve ölçekteki sorulara verilen yanıtların ortalamalarının varyans analizi sonuçlarına bakıldığında akademisyen görüşlerinin sınava giriş nedenlerine göre anlamlı farklılıklar gösterdiği bulunmuştur $(\mathrm{p}<0.05)$. Bu analizden hareketle hangi grupların ortalamaları arasında fark olduğunu belirleyebilmek amacıyla Tablo 11'de verilen Tamhane çoklu karşılaştırma testi yapılmıştır.

Tablo 17. YDS'ye Giriş Nedenine Göre Yapılan Çoklu Karşılaştırmalar

\begin{tabular}{|c|c|c|c|c|c|c|c|}
\hline & & \multicolumn{3}{|c|}{ Tamhane Çoklu Karşılaştırmalar } & \multirow[b]{2}{*}{ Kadro } & \multirow[b]{2}{*}{ Dil. S. } & \multirow[b]{2}{*}{ Diğer } \\
\hline & & & Tazminat & Lisnsüst. & & & \\
\hline \multirow[t]{5}{*}{ Kapsam Geç. } & $\mathrm{p}$ & Tazminat A. & - & .005 & .001 & .863 & 1.000 \\
\hline & & Lisns üst. Ĕ & .005 & - & 197 & .001 & .014 \\
\hline & & Kadro alma & .001 & 197 & - & .001 & .912 \\
\hline & & Dil sev. öğr. & .863 & .001 & .001 & - & 1.000 \\
\hline & & Diğer & 1.000 & .014 & .912 & 1.000 & - \\
\hline \multirow[t]{5}{*}{ Kriter Geç. } & $\mathrm{p}$ & Tazminat A. & - & .002 & .004 & .424 & .867 \\
\hline & & Lisns üst. Ĕg & .002 & - & .157 & .001 & .951 \\
\hline & & Kadro alma & .004 & .157 & - & .047 & .994 \\
\hline & & Dil sev. öğr. & .424 & .001 & .047 & - & .077 \\
\hline & & Diğer & .897 & .951 & .994 & .077 & - \\
\hline \multirow[t]{5}{*}{ Yordamlama } & $\mathrm{p}$ & Tazminat A. & - & .017 & .001 & .086 & .936 \\
\hline & & Lisns üst. Ĕg & .017 & - & .866 & .999 & .978 \\
\hline & & Kadro alma & .001 & .866 & - & 1.000 & .519 \\
\hline & & Dil sev. öğr. & .086 & .999 & 1.000 & - & .913 \\
\hline & & Diğer & .936 & .978 & .519 & .913 & - \\
\hline
\end{tabular}

Analiz verileri çoklu karşılaştırma sonuçlarını verecek biçimde Tablo 17'de özetlenmiştir. Akademisyenlerin ölçekte yer alan sorulara verdikleri cevaplar arasındaki ilişkiye bakıldığında YDS Kapsam Geçerliği alt boyutunda sinava tazminat almak için girenlerin cevaplarıyla lisansüstü eğitim almak ve akademik kadro almak için girenlerin cevapları arasında anlamlı fark çıkarken, yabancı dil seviyesini öğrenmek 
ya da başka nedenler için (değişim programlarına katılabilmek, eğitim dilinin İngilizce olduğu derslere girebilmek vs.) sinava girenlerin cevaplarıla arasında anlamlı fark çıkmamıştır ( $\mathrm{p}<0.05)$. Bu sonuçlar ortaya çıkan bu farklılı̆̆ın katılımcıların sınava girerken ki motivasyonlarının farklı olmasından kaynaklanıyor olabilir. YDS’ye kadro almak veya lisansüstü eğitim almak için girenlerin içsel motivasyonlarının son derece yüksek olduğunu söylemek yanlış olmayacaktır. Zira bu sayede iş bulabilecekler veya işlerinde ilerleme şansı bulabilmek için eğitim alacaklardır. Öte taraftan karşılaştırıldığında kadro almak ya da eğitime devam edebilmek gibi çok önemli nedenleri olmayan akademisyenlerin Türkiye'de çok da önemli sayılmayacak miktarlardaki dil tazminatları için sınava girerken aynı motivasyona sahip olacakları pek mantıklı bir çıkarım olmayacaktır. Lisansüstü eğitim veya kadro almak için sınava giren akademisyenlerin yanitları YDS Kriter Geçerliği alt boyutunda da tazminat almak veya bunlar dışında başka nedenler için sinava giren katılımcıların yanıtlarına göre anlamlı farklılık göstermiştir $(\mathrm{p}<0.05)$. Tazminat almak için sinava girenlerin yantları YDS Yordamlama alt boyutunda lisansüstü eğitim veya kadro almak için s1nava giren akademisyenlerin yanıtlarına göre anlamlı farklılık gösterdiği göze çarpmaktadır. Bütün bu alt boyutlarda yabancı dil sinavina girerken katılımcıların amaçlarının dil öğrenme davranışlarını ve gerek yabancı dille gerekse YDS ile ilgili fikirlerini etkileyebileceği söylenebilir.

\section{Sonuç ve Öneriler}

2015-2016 yılları arasında yapılan ve akademisyenlerin YDS'nin geçerliğiyle ilgili tutumlarının belirlenmesi amaçlanan bu çalışmada elde edilen sonuçlara göre:

a) Katılımcıların YDS'nin geçerliğiyle ilgili görüşlerinin kişisel özelliklerine göre (cinsiyet ve medeni durum) farklılık göstermediği tespit edilmiștir.

b) Katılımcıların YDS’nin geçerliğiyle ilgili görüşlerinin akademik unvanlarına göre anlamlı farklılık gösterdiği bulunmuştur. Bu farklılık incelendiğinde akademisyenlerin YDS'nin geçerliği ve sınav etkisiyle ilgili verdikleri cevaplar bazında unvanlarına göre üç ana gruba ayrıldıkları tespit edilmiştir. Buna göre öğretim görevlileri ve uzmanlar birinci grup, asistan, yardımcı doçent, doçentler ikinci grubu ve en son okutmanlar ve profesörler üçüncü grubu oluşturmuştur. Bu akademisyenlerin neden bu şekilde ayrıştıkları sorgulandığında yabancı dil yeterliğiyle ilgili kimlerin daha rahat olduğu, belirli kadrolar için süre korkusunun bulunup bulunmadığ 1 veya akademik yükselme anlamında yabancı dil yeterliğine daha çok ihtiyaç duyup duymadığı gerçeği öne çıkar. Türkiye’deki mevcut akademik sistemde bir öğretim görevlisi, uzman veya okutmanın işe başladıktan sonra eğer lisansüstü eğitim yapmayacak veya başka akademik kadrolara başvurmayacaksa zaman içerisinde dil yeterliğini tekrardan belgelemesine gerek yoktur. Öğretim görevlisi ve uzmanların yabancı dil yeterliğiyle ilgili diğer akademisyenlere göre kendilerini daha rahat hissetmelerinin temel nedeni budur ve bu yüzden dil yeterliğiyle ilgili sorulara verdikleri cevapların farklı çıması beklenebilir (bu çalışmada yer alan okutmanların tamamı yabancı dil eğitimi veren hocalar olduğu, öğretim görevlisi ve uzmanların hiçbirinin yabancı dilci olmadığı hususu da hatırlanmalıdır). Öte yandan okutmanların dil eğitimi ile uğraşan akademisyenler olması nedeniyle YDS konusunda diğer akademisyenlerden daha avantajlı oldukları ve aynı öğretim görevlisi ve uzmanlar gibi herhangi bir zaman kısıtlamasına tabii olmadiklarından sınavla ilgili bir endişelerinin olmaması da cevaplarında farklı davranmalarına yol açmış olabilir. Benzer bir durum profesörler içinde geçerlidir, doçentlik için gereken dil yeterliği elde edildikten sonra onlarda dil yeterliği gereklilikleri düşünüldüğünde benzer rahatlığa sahip olurlar yani artık dil yeterliğini ispata gerek yoktur. Bütün bunların yanında özellikle asistan ve yardımcı doçent kadrolarına sahip akademisyenlerin belirli bir zamana kadar belirli puanları alma gayreti onları başka akademisyenlerden ayırmaktadır çünkü önlerinde hem zaman kısitlaması hem de arkadan gelen başka akademisyenler vardır. Yabancı dil yeterliği bu anlamada edinilmesi gereken önemli becerilerden bir olmaktan ziyade aşılması gereken bir engel gibi algılanmakta ve bu 
yüzden yeterliğe olan ilgi sınavı geçene kadar sürdürülmekte, sonrasında çoğunlukla önemsenmemektedir.

c) Katılımcıların YDS’nin geçerliğiyle ilgili görüşlerinin YDS'ye girme nedenlerine ve sinavdan aldıkları nota göre farklılık gösterdiği anlaşılmıştır. Bu farklılı̆̆ın nedenlerine bakıldığında, özellikle tazminat almak, dil seviyesini öğrenmek ve başka benzer nedenler için sınava girenlerin YDS Kapsam ve Kriter Geçerliği alt boyutlarında kadro almak veya lisansüstü eğitim yapmak için sınava girenlerden farklı davrandıkları görülmüştür. Sınavdan aldıkları notlar ele alındığında akademisyenlerin 80 ve üzeri not alanlarının 60 'dan düşük not alanlarla benzer davrandıkları görülürken 6079 arasında notlar alanların diğer gruplardan anlamlı şekilde farklı davrandıkları bulunmuştur. Sonuç olarak, notları bazında katılımcıların 3 gruba ayrıldıkları (60'dan düşük alanlar. 60-80 arası alanlar ve 80 'den yukarı not alanlar) ve alt grupla en üst gruptakilerin biri başarı diğeri başarısızlık yüzünden daha rahat davrandıkları; ancak orta grupta yer alan akademisyenlerin kritik notlara yakınlıkları yüzünden diğer katılımcılara nazaran daha fazla etkilendikleri söylenebilir. Bu yüzden alt ve üst grup not alan katılımciların cevapları arasında anlamlı fark çıkmazken orta grupta yer alan katılımcılar bu iki gruptan farklı davranmışlardır.

d) YDS’nin geçerliğiyle ilgili maddelere akademisyenler çoğunlukla olumsuz görüş bildirmişler ve sınavın içeriğinin yabancı dil ölçme konusunda yetersiz olduğunu dile getirmişlerdir. Bu konuda en olumsuz görüşler okutman ve profesörlerden gelirken, YDS’nin dil ölçme anlamında geçerlik kazanabilmesi için içeriğine mutlaka kısada olsa konuşma, yazma ve dinleme soruları dâhil edilmesi gerektiği belirtilmiştir. Ancak sınavda dinleme, konuşma ve yazma bölümleriyle ilgili isteklerin sahipleri unvan bazında ele alındığında \%35'inin okutmanlar. \%32'sinin profesörler. \%17'sinin doçentler olduğu anlaşılmıştır. Yani ortaya çıkan bu oranlar YDS'de en başarılı katılımcı gruplarının bu konuda değişiklik istedikle- rini gösteriyor. Yardımcı doçentlerin sadece \%2'si dinleme, yazma vs. isteğinde bulunurken asistanlarda bu oran \%4'tür. Ortaya çıkan bu tabloda bizlere şu soruyu sorduruyor; eğer YDS’nin içeriği tamamen değiştirilse ve içerisinde iletişimsel becerilerin olduğu bu yeni sınava akademisyenlerin tamamının girmesi şart koşulsa katılımcıların böylesi bir değişime tepkisi aynı yönde olur muydu? Tabii YDS'nin içerisinde yukarıda bahsedilen becerilerin bulundurulması konusu çok da yeni ve daha önceden üzerinde hiç durulmamış bir konu değildir. Bu husus elbette ÖSYM yetkilileri tarafından da dile getirilmiş ancak bu becerilerin nasıl ölçüleceği, ölçümün ne kadar zamanda ve kimler tarafından yapılacağı, bu değerlendiricilerin ne kadar objektif davranacakları konuları masaya yatırılmış ve her biri üzerinde durulması ve aşılması gereken birer engel olarak açıklanmıștır. Ayrıca hâlihazırda YDS içinde yer alan çoktan seçmeli dilbilgisi, okuma ve çeviri sorularının varlığ 1 da sınavı hazırlayan yetkililerce gerek ölçmede sağladığ1 avantajlar ki bunların başında güvenilir ve hızlı olması belirtilmiştir, gerekse Türkiye’de mevcut yabancı dil eğitimi alışkanlıklarının ve geleneğinin kaçınılmaz bir yansıması olarak açıklanmıştır ki Türkiyede özellikle devlet ortaokul ve lise yabancı dil müfredatları hatırlandığında hiç de haksız sayılmazlar.

Öneriler kısmındaysa çalı̧̧madan elde edilen bulgular üzerinden bazı tespitler yapıp bu tespitlere paralel öneriler yapmak yerinde olacaktır. Ayrı ayrı ele alındığında yabancı dilde konuşma, yazma gibi becerilerin ölçülmesinde ölçmenin geçerliği ve güvenirliğiyle, alacağı zaman ve organizasyonuyla ilgili doğabilecek sorunlar konuyla ilgili herkesin malumudur ancak bu sorunlar uluslararası yabancı dil sinavlarının nasıl yapıldığıyla ilgili esaslar hatırlandığında çözümlenemeyecek sorunlar değillerdir. Burada önemli olan günümüzde dil ölçmede gerçekten ne gibi ihtiyaçların ortaya çıktığının farkına varılması, konuyla ilgili kurumların organize olmaları ve aşamalı olarak bu sınavların hazırlanmasıyla ilgili kararlı adımlar atılması gerçeğinin kabul edilmesi ve buna uygun eylem planı hazırlanmasıdır. Bu çalışmada ortaya çıkan YDS’nin geçerliğiyle ilgili olumsuz tablo aslında eğitim çevrelerine şu gerçeği de anlatabilir, ölçme ve değerlendir- 
me metotları artık eğitim sürecinin bir ürünü ve son halkası olarak değerlendirilmemeli tam aksine süreci belirleyen ve birçok noktasına etki eden bir aşama olarak görülmelidir çünkü günümüzde eğitim alanlar daha sürecin en başında ne tarz bir değerlendirme yapılacağını, değerlendirmenin içerisindeki ögeleri öğrenir ve kendi öğrenme stratejilerini buna uygun tasarlar. Bu nedenledir ki dil yetkinliği denilince akla ilk gelen beceriler konuşma, dinleme, okuma-anlama ve yazma olmalıdır, bu gruptan birinin veya birkaçının süreç dışında tutulması sadece ölçmenin geçerliğini tehlikeye atmakla kalmaz eğitim sürecini de doğrudan etkiler.

Türkiyede yabancı dil yeterliğiyle ilgili uygulamalar değiştiğinde, örneğin sınavlar ağırlıklı olarak dinleme, konuşma ve yazma gibi beceriler üzerine hazırlandığında sinava gireceklerin bu sinavlara nasıl hazırlanacakların, neleri önemseyeceklerini, eğitimcilerden neleri talep edeceklerini ve eğitim programlarının hangi becerilerin öğretimine yoğunlaşacaklarını tahmin etmek zor olmayacaktır. $\mathrm{Bu}$ araştırma Türkiye'de böylesi bir ihtiyacın var olduğunu ve yabancı dil ölçümü bazında böylesi değişimin gerçekleşmesi gerekliliğini ortaya çıkarmıştır. Akademisyenlerin dil yeterliği konusunda ihtiyaçlarının farkında olduğu gerçeği ve bu konuda desteklenmeleri için sınav içeriklerinin de yeniden düzenlenmesi gerekliliği açıktır. 2017 yllında Türkiye’nin teknolojik anlamda dünya ülkelerinin gerisinde olmadığı ve eldeki imkânlar kullanılarak pekâlâ bilgisayar destekli dil sınavları hazırlanabileceği, bu sınavlardan elde edilecek verinin sertifikalı ve konusunda uzman bir değerlendirici topluluğu tarafından yılda iki kere değil de çok daha fazla sayıda oturumlarda değerlendirilebileceği düşünülmelidir. Bazı kurumların onlarca yıldır yapabildikleri bu dil sinavlarının benzerleri istenirse Türkiye'de de yapilabilir, yeter ki bu konudaki ihtiyacın ve mevcut rahatsızlığın farkına varılsın ve bu konuda başı çekecek eğitim kurumları YÖK ve ÖSYM'ye destek versin.

Önemli bir diğer bulguda akademisyenlerin alanlar1na bakılmaksızın yabancı dil yeterliğine sahip olup olmaları konusundadır. Katılımcıların \%73'ü böyle bir gerekliliğin olmadığını savunmuş ve bu konuda alınacak dil yeterliğinin eğer doğru dilde değilse bir anlam ifade etmeyeceğini dile getirmişlerdir. Bu konuyu savunanların kimler olduğuna bakıldığında ise unvan bazında özellikle yardımcı doçentlerin ön plana çıktığ $(\% 41)$, bu hususa katılmayanların ise önce profesörler (\%43) daha sonrada okutmanlar (\%29) olduğu anlaşılmıştır. Alan bazında bakıldığında da özellikle fen bilimlerinden katılan katılımcıların (\%51) bu görüşü savunduğu belirlenmiştir. Bu noktada dil yeterliği kimlere gerekli olmalıdır ve bu konuda dil seçimi akademisyene mi bırakılmalıdır sorusunun üzerinde durmak yararlı olacaktır. Örneğin İngiliz Dili Eğitiminde çalışan bir akademisyen yabancı dil sınavında İtalyanca dil yeterliğine sahip olduğunu belgelerse, alanıyla ilgili bu dilde mi araştırma yapacaktır ve eğer uzmanlık alanı olan İngilizcede yeteri kadar kaynağa ulaşabiliyorsa İtalyanca dil yeterliği bu akademisyen için ne denli anlamlı olacaktır? Öte yandan fen bilimlerinden bir akademisyenin herhangi bir yabanc1 dilden sözgelimi Macarcadan dil yeterliğini belgelemesi aslında ne kadar önemli bir yeterlilik olacaktır? $\mathrm{Bu}$ yeterliklerle ilgili gerçekçi tespitlere ve mantıkll, izah edilebilir çerçevelere ihtiyaç vardır. Çalışmadan elde edilen bu bulgu üzerinde araştırılma yapılması gereken bir diğer sorun olarak gösterilebilir.

Yabancı dil yeterliği ölçümüyle ilgili yapılabilecek bir diğer öneride bu sınavlarının ne sıklıkla yapılması ve sınavlardan alınacak notların hangi dil becerilerinin ne ölçüde test edildiğinin belirlenmesi hususunda olacaktır. Örneğin, YDS'den alınan notlar eğer dil tazminatı alabilmek için kullanılıyorsa 5 yılda bir yenilenmesi gerekmektedir aksi takdirde kişinin dil tazminatında 10 puanlık dilimler halinde 5 yılda bir azaltılmaya gidilmektedir. Mesela 90 puan almış bir akademisyen için verilen dil tazminatı 5 yıl içerisinde tekrar sinava girip yenilenmezse 80 puanlık dilimde ödenmektedir. Ancak benzer bir uygulama akademisyenlerin kadro almak için edindikleri dil yeterlik puanına uygulanmamaktadır yani 90 puan almış bir asistan ya da yardımcı doçent bir daha hiç sınava girmese de kendisinden zaman içerisinde bir yenileme istenmemekte, kendisinin akademik kariyeri boyunca dil yeterliğine sahip olduğu varsayımı yapılmaktadır. Bu çeliş̧inin hiçbir bilimsel izahı ve ÖSYM tarafından açıklanan bir gerekçesi yoktur ve öngörülen 5 yılın neden 5 yıl olduğu konusu da başka bir soru işaretidir. Eğer yabancı dil yeterliği akademisyenler için bu denli önemliyse neden sonrasında bu yeterliğin belirli zaman dilimleri içerisinde tekrar istenmediği, istenilip istenilmemesi gerektiği ise başka araştırma konuları olabilir. 
Çalışmadan elde edilen sonuçlara bakıldığında yapılabilecek başka bir öneride ÖSYM'nin yaptığı farklı dillerde YDS'lerin birbirleriyle ne ölçüde denk olduğu, hatta aynı dilde farklı zamanlarda yapılan YDS'lerin zorluk derecelerinin ne ölçüde örtüştüğü konusunda olabilir. Çalışmaya katılan akademisyenler zaman zaman sinavin kolay sayılabilecek seviyede olduğunu zaman zamansa oldukça zor soruların çıktığını belirtmişler, bir katılımcı bahar ve sonbahar dönemlerinde yapılan sinavın bahar döneminde daha çok katılımcı olduğundan soruların daha zor sorulduğu sonbaharda ise daha kolay olabildiğini belirtmiştir. Bu iddianın ne derece doğru olduğu tabii ki bir bilimsel çalışma yapmadan test edilemez ancak yıllar bazında sınava giren katılımcıların sayısına ve ortalamalara bakıldığında karşılaşılan ilginç bir gerçekte sonbaharda yapılan YDS'den ortalama bazında daha yüksek notlar alındığı, katılımcı sayısında ise bahar dönemindeki sınavda daha fazla katılan olduğu ancak notların sonbahar dönemlerine kıyasla (\%10-30 arasında değișen oranlarda) düşük çıktığı görülmüştür. Bu durumun bir tesadüf olup olmadığ 1 da yine araştırma yapılması gereken konulardandır. Buna ek olarak farklı dillerde aynı dönemde yapılan YDS testlerinin denkliği de ayrı bir merak konusudur zira bir katılımcının da belirttiği üzere belirli bazı dillerden sınava girmenin adaya bir avantaj sağlayıp sağlamayacağı araştırılmalı, örneğin bir Macarca testinin İngilizce veya Almanca testiyle aralarında sinavın zorluğu anlamında bir fark olup olmadığ 1 konusunda bilimsel çalışma yapılmalıdır.

Konuyu toparlamak gerekirse, YDS ile ilgili değerlendirmeler yapılırken Türkiyedeki yabancı dil eğitimi ile ilgili genel sorunlar görmezlikten gelinmemelidir. Birçok araştırmacı bu konu üzerinde araştırma yaparken eğitim kurumlarının dil eğitimindeki amaçları, eğitim politikaları, eğitici kalitesi, kullanılan materyaller, motivasyon gibi hususlara değinirlerken, sorunun ölçme değerlendirme boyutu ne yazık ki gereği kadar irdelenmemiştir. Türkiye'de mevcut yabancı dil sınavlarının neredeyse tamamı çoktan seçmeli sınavlar șeklinde yapılmakta, bu sınavlarda çoğunlukla dilbilgisi ve okuma becerileri ölçülmektedir ancak paydaşlara soruduğunda gerek bu sinavları hazırlayanlar, gerekse bu sinavlara katılanlar bu durumun neden böyle olduğunu ve ileride ne olacağını açıklamakta sıkıntı çekmektedirler. Yabancı dil sınavlarında çoğunlukla benimsenen dilbilgisi, kelime ve okuma-anlama sorularının yabancı dil yeterliği ölçü- münde ne denli kestirimsel geçerliğe sahip olduğu bir muammadır. YDS'nin kestirimsel geçerliği ile ilgili mutlaka bilimsel çalışmalar yapılmalı ve bu tarz bir ölçmenin günümüzde oldukça demode hale geldiği ve sonuçlarının paydaşlarca yeterli görülmediği halde neden hala ısrarla uygulandığının nedenleri tüm paydaşlarca masaya yatırılmalıdır.

\section{Kaynakça}

Altmışdört. G. (2010). Yabancı Dil Öğretiminde Nasıl Bir Ölçme-Değerlendirmeye İhtiyaç Vardır. Kuramsal Eğitimbilim. 3(2). 175-200.

Anderson. J. C., Gerbing. D. W. (1984). The effect of sampling error on convergence. Improper solutions and goodness of fit indices for maximum likelihood confirmatory factor analysis. Psychometrika. 49. 155-73. doi: 10.1007/BF02294170.

Aşkaroğlu. V. (2014). 2013 YDS ile 2012 KPDS ÜDS Sınavlarının karşılaş̧ırılması. Karadeniz Blacksea Chornoye More, 21. 1-13.

Aydın, B., Akay, E., Polat, M., Geridönmez, S. (2016). Türkiyedeki Hazırlık Okullarının Yeterlik Sınavı Uygulamaları ve Bilgisayarlı Dil Ölçme Fikrine Yaklaşımları. Anadolu Üniversitesi Sosyal Bilimler Dergisi, 16 (2), 1-19.

Bayraktaroğlu. S. (2010). Yabancı Dil Eğitimi Gerçeği. Yabancı Dilde Eğitim Yanılgısı. Cumhuriyet Bilim ve Teknik (CBT1221/18).

British Council Report. (2015). Türkiyede Yükseköğretim Kurumlarmdaki İngilizce Eğitimi. (RaporNo:2016021). British Council'dan edinilmiştir. http:// www.britishcouncil.org.tr/sites/default/files/20160211_ english_he_baseline_study_final_tr.pdf

Brown. J. D. (1998). Testing in Language Programs. Upper Saddle River. NJ: Prentice Hall Regents.

Browne M., W. Cudeck R. (1989). Single sample crossvalidation indexes for covariance structures. Multivariate Behavioral Research. 24 (4). 445-55. doi: 10.1207/s15327906mbr2404_4. 
Büyüköztürk. Ş. (2013). Sosyal Bilimler İçin Veri Analizi El Kitabı. Ankara. Turkey: Pegema Yayıncılık

Çelik. Duran. (2000). Okullarda Ölçme ve Değerlendirme Nasıl Olmalı? MEB Yayını. İstanbul.

Cohen. R.J.. Swerdlik. M.E. (2013). Psikolojik test ve değerlendirme. Testler ve ölçmeye giriş [Psychological testing and assessment. an introduction of test and measurement] E. Tavşancıl (Ed.\& Trans.). Ankara: Nobel Yayıncilı.

Crocker. L. Algina. J. (1986). Introduction to Classical and Modern Test Theory. Orlando. FL: CBS Collage Publishers Canpany.

DeVellis. R. F. (2014). Ölçek Geliştirme. Kuram ve Uygulamalar (Ed. Tarık Totan). Ankara: Nobel Yayıncllik.

ElAita. S. (2013). Test Translation and Adaptation.. (Editör: D. Tsigari. The Language Dimension). Translation in Language Teaching and Assessment. Cambridge: Cambridge University Press.

Ercan. İ.. Kan. İ. (2004). Ölçeklerde Güvenirlik ve Geçerlik. Uludağ Üniversitesi Tip Fakültesi Dergisi. 30 (3) 211-216.

ESI. (2014). Türk Öğrenciler. Tecrit ve Erasmus Sorunsalı. ESI Arka Plan Araştırması. European Stability Initiative kurumundan edinilmiştir. http://www. esiweb.org/pdf/Turk\%20Ogrenciler.\%20Tecrit\%20 ve\%20Erasmus\%20Sorunsali\%20(24\%20Temmuz $\% 202014$

ETS. (2015). TOEFL IBT and IELTS Academic Module Scores. ETS Home web sayfasından edinilmiştir. https://www.ets.org/toefl/institutions/scores/compare

Gür. Ö. (2012). Ölçme. Değerlendirme ve Kamu Personeli Dil Sınavı (KPDS)- Bu Sınav Neyi Ölçüyor. Sakarya Üniversitesi Eğitim Dergisi. Sayı:2/1. ISSN: 2146-7455

Heaton. J. B. (1988). Writing English Language Tests. Longman Handbook for Language Teachers. Longman.
Henning. G. (1992). Dimensionality and Construct Validity of Language Testing. Language Testing. 06/1992-9.1.

Hu L. T. Bentler P. M. (1999). Cut off criteria for fit indexes in covariance structure analysis: Conventional criteria versus new alternatives. Structural Equation Modeling: A Multidisciplinary Journal. 1(6). 1-55.

İngilizce Öğretmeni Bile Tercümansız Konuşamıyor. (2008, 4 Ocak). Vatan. http://www.gazetevatan. com/ingilizce-ogretmeni-bile-tercumansiz-konusamiyor----155119-gundem adresinden edinilmiştir.

Jöreskog. K. G..Sörbom. D. (1993). Lisrel 8: Structural Equation Modeling With the Simplis Command Language. Hillsdale: Erlbaum Associates Publishers.

Karaman. F. (2015). Yabancı Dil Sinavinın Almanca Ölçme Aracı Olarak Değerlendirilmesi. Route Educational and social Science Journal. Say1: 2(1). Ocak 2015.

Kline. R. B. (2005). Principles and Practice of Structural Equation Modeling. NewYork: The Guilford Press.

Koru. S. Akesson. J. (2011). Turkey's English Deficit. Economy Policy Research foundation of Turkey. (RaporNo:201157). TEPAV'dan edinilmiştir. http:// www.tepav.org.tr/upload/files/1324458212-1. Turkey_s_English_Deficit.pdf

Kozallık. R. H. Ç.. Karakaya. Z. (2015). Lisansüstü Seviyede Yabancı Dil Sorunları. International Periodical For The Languages. Literature and History of Turkish. Volume: 10/2 Winter 2015. P. 183-192. doi:10.7827/TurkishStudies.7857

Marsh. H. W.. Balla. J. R. ve McDonald. R. P. (1988). Goodness-of-fit indices in confirmatory factor analysis: The effect of sample size. Psychological Bulletin. 3(103). 391-410.

Messick. S. (1996). Validity and Washback in Language Testing. Educatonal Testing Service (ETS). Princeton. US. 
Oktay. A. (2015). Foreign language teaching: A problem in Turkish education. Procedia - Social and Behavioral Sciences. 174 (2015) 584 - 593. doi: 10.1016/j.sbspro.2015.01.587

ÖSYM. (2015) (b). Yabancı Dil Sınavları Eşdeğerlikleri. ÖSYM'den elde edilmiştir. http://dokuman. osym.gov.tr/pdfdokuman/2015/genel/EsdegerlikTablosu14012015.pdf

Özdamar. K. (2013). Paket Programlar ile İstatistiksel Veri Analizi (9. Baskı). Eskișehir: Nisan Kitabevi. 1. Cilt.

Özmen. K. S. (2011). Washback Effects of Inter University Foreign Language Examination on Foreign Language Competences of Candidate Academics. Novitas Royal (Research on Youth and Language). 5(2). 215-228.

Sun. Y., Cheng. L. (2013). Assesing Second/Foreign Language Competence Using Translation. Chinese Case. (Editör: D. Tsigari). Translation in Language Teaching and Assessment. Cambridge University Press.

Şeker. H., Gençdoğan. B. (2014). Psikolojide ve Eğitimde Ölçme Aracı Geliştirme. Ankara: Nobel Yayıncılik.
Şencan. H. (2005). Sosyal ve Davranışsal Ölçümlerde Güvenirlik ve Geçerlik. Ankara; Seçkin Yayıncılık.

Şimşek. Ö. F. (2007). Yapısal eşitlik modellemesine giriş: Temel ilkeler ve LISREL uygulamalari. İstanbul: Ekinoks Yayınları

Sümer. N. (2000). Yapısal Eşitlik Modelleri: Temel Kavramlar ve Örnek Uygulamalar. Türk Psikoloji Yazıları, 6(3). 49-73.

Tekin. H. (1977). Eğitimde Ölçme ve Değerlendirme. Mars Matbaası. Ankara.

Vieira. A. L. (2011). Preparation of the analysis. Interactive LISREL in practice. (First Edition). London: Springer.

Yavuzer, H., Göver, İ. H. (2012). Akademik Personelin Yabancı Dil Durumu ve Yabanci Dil Sinavlarına bakışı: Nevşehir Örneği. Nevşehir Üni. Sosyal Bilimler Enst. Dergisi. 136-158.

Yıldırım, C. (1983). Eğitimde Ölçme ve Değerlendirme: Öğretmenler İ̧̧in El Kitabı. ÖSYM Eğitim Yayınlar1:7. Ankara.

Yllmaz, H. (1996). Eğitimde Ölçme ve Değerlendirme. Öz Eğitim Basımevi. Konya. 


\section{Ek A}

\section{YDS Geçerlik Tutum Ölçeği}

\section{Sayın Katılımcı,}

Bu bilgi formu “Türkiye'de Yapılan Yabancı Dil Bilgisi Seviye Tespit Sınavı'nın (YDS) Geçerliği Üzerine Bir Inceleme" adlı çalışmaya veri toplamak amacıyla hazırlanmıştır. Birinci bölümde, kişisel bilgileriniz ve YDS deneyimlerinizle ilgili sorular; ikinci bölümde YDS'nin geçerliği ve son bölümde YDS'nin ket vurma etkisi ile ilgili ifadeler yer almaktadır. Lütfen size uygun olan seçeneği (X) ile işaretleyiniz. Soruları cevaplamanız aynı zamanda verdiğiniz bilgilerin çalışmada kullanımına onay vermeniz anlamına gelecek ve vereceğiniz cevaplar tamamen bilimsel amaçlar için kullanılacaktır.

\section{Bölüm Kişisel Bilgiler}

1. Cinsiyetiniz:

2. Medeni durumunuz:

3. Yaşadığınız şehir:

4. Çalıştığınız kurum:

5. Akademik ünvanınız:
Katılım ve katkılarınız için teşekkür ederim.

Uzman ( ) Okt. ( ) Öğr. Gör. ( ) Arş. Gör. ( ) Yrd. Doç. Dr. ( ) Doç. Dr. ( ) Prof. Dr. ( )

6. Alanınız:

Sosyal Bilimler ( ) Fen Bilimleri ( )

Kadin ( )

Erkek ( )

Bekâr ( )

Evli ( )

7. YDS'ye kaç kere katıldınız: $\quad 0(\quad)$

Sağlık Bilimleri ( )

Eğitim Bilimleri ( )

Diğger ( )

8. Sinavdan alınan en son puan: .............

$$
1-2(\quad)
$$$$
\text { 3-4 ( ) }
$$

5 ve üstü ( )

9. Sınava giriş nedeni:

$$
\text { Yabancı Dil Tazminatı Almak }
$$

$(\quad)$

Lisans Üstü Eğitim ( )

Akademik Kadro Almak ( )

Yabancı Dil Seviyemi Öğrenmek ( ）

Diğer ( )

10. Sınava hazırlanırken: Hiç çalışmadım ( ） Kendim çalışıp hazırlandım ( ） Dershaneye gittim ( ) Özel ders aldım ( ) Çevrimiçi kurslara katıldım ( ) Diğer ( )

11. YDS dışında YDS'ye denkliği kabul edilen aşağıdaki sınavlardan herhangi birine katıldınız mı ve katıldıysanız bu sınavdan en son kaç puan aldınız:

Katılmadım ( ) TOEFL ( ) Puan: ....

IELTS ( ) Puan:

PTE ( ) Puan: 


\section{Bölüm YDS Geçerlik}

\begin{tabular}{|c|c|c|c|c|c|c|}
\hline Sira & Yabancı Dil Bilgisi Seviye Tespit Sınavı (YDS); & 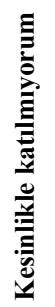 & 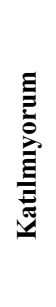 & 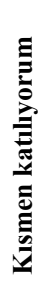 & 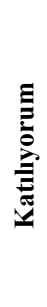 & 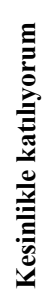 \\
\hline 1 & $\begin{array}{l}\text { soruları Türkiye'de edinilmesi istenilen yabancı dil } \\
\text { becerilerinin ölçümüne uygundur. }\end{array}$ & & & & & \\
\hline 2 & $\begin{array}{l}\text { puanı uluslararası geçerli herhangi basska bir yabancı dil } \\
\text { testinden alınan dil yeterlilik puanı ile benzer çıkacaktır. }\end{array}$ & & & & & \\
\hline 3 & $\begin{array}{l}\text { yabancı dili yurtdışında yaşayarak veya bir süreliğine } \\
\text { kalarak öğrenmiş adaylar için kolaydır. }\end{array}$ & & & & & \\
\hline 4 & yabancı dil seviyesini ölçebilen bir sınavdır. & & & & & \\
\hline 5 & puanı adayın gerçek yabancı dil seviyesini gösterir. & & & & & \\
\hline 6 & $\begin{array}{l}\text { sorularını çözebilmek için o yabancı dili iyi bilmek } \\
\text { yeterlidir. }\end{array}$ & & & & & \\
\hline 7 & $\begin{array}{l}\text { sorularının bütünü yabancı dil seviyesini ölçmeye } \\
\text { uygundur. }\end{array}$ & & & & & \\
\hline 8 & $\begin{array}{l}\text { puanı yabancı dil seviyesi ile ilgili alınacak kararlarda tek } \\
\text { basına gecerli olmalıdır. }\end{array}$ & & & & & \\
\hline 9 & $\begin{array}{l}\text { sonunda } 90 \text { ve üstü alan bir aday o yabancı dili ileri } \\
\text { düzeyde kullanabilir. }\end{array}$ & & & & & \\
\hline 10 & $\begin{array}{l}\text { sorularının bütünü yapısal bir bütünlük oluşturacak biçimde } \\
\text { birbirleriyle ilişkilidir. }\end{array}$ & & & & & \\
\hline 11 & $\begin{array}{l}\text { alanına bakılmaksızın bütün akademisyenlerin meslekî } \\
\text { gelişimleri için gerekli olan bir sınavdır. }\end{array}$ & & & & & \\
\hline 12 & yabancı dil seviyesini ölcmek icin ivi bir arac değildir. & & & & & \\
\hline
\end{tabular}

